\title{
Antibacterial Bio-Based Polymers for Cranio-Maxillofacial Regeneration Applications
}

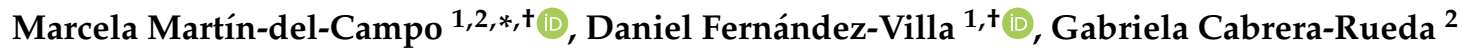 \\ and Luis Rojo $1,3, * \mathbb{D}$ \\ 1 Instituto de Ciencia y Tecnología de Polímeros, Consejo Superior de Investigaciones Científicas, CSIC, \\ 28006 Madrid, Spain; danielfv@ictp.csic.es \\ 2 Facultad de Estomatología, Universidad Autónoma de San Luis Potosí, Av. Dr. Salvador Nava No. 2, \\ Zona Universitaria, San Luis Potosí (S.L.P.) 78290, Mexico; gabriela.cabrera@uaslp.mx \\ 3 Consorcio Centro de Investigación Biomédica en Red de Bioingeniería, Biomateriales y \\ Nanomedicina (CIBER-BBN), Calle Monforte de Lemos S/N, 28029 Madrid, Spain \\ * Correspondence: marcela.martincampo@uaslp.mx (M.M.-d.-C.); rojodelolmo@ictp.csic.es (L.R.); \\ Tel.: +34-911-765-013 (M.M.-d.-C.); +34-915-622-900 (L.R.) \\ + These authors contributed equally to this work.
}

Received: 3 November 2020; Accepted: 22 November 2020; Published: 25 November 2020

\begin{abstract}
Cranio-maxillofacial structure is a region of particular interest in the field of regenerative medicine due to both its anatomical complexity and the numerous abnormalities affecting this area. However, this anatomical complexity is what makes possible the coexistence of different microbial ecosystems in the oral cavity and the maxillofacial region, contributing to the increased risk of bacterial infections. In this regard, different materials have been used for their application in this field. These materials can be obtained from natural and renewable feedstocks, or by synthetic routes with desired mechanical properties, biocompatibility and antimicrobial activity. Hence, in this review, we have focused on bio-based polymers which, by their own nature, by chemical modifications of their structure, or by their combination with other elements, provide a useful antibacterial activity as well as the suitable conditions for cranio-maxillofacial tissue regeneration. This approach has not been reviewed previously, and we have specifically arranged the content of this article according to the resulting material and its corresponding application; we review guided bone regeneration membranes, bone cements and devices and scaffolds for both soft and hard maxillofacial tissue regeneration, including hybrid scaffolds, dental implants, hydrogels and composites.
\end{abstract}

Keywords: Bio-based polymers; antibacterial; cranio-maxillofacial regeneration; dentistry; tissue engineering; chitosan; guided bone regeneration membranes; bone cements; biomedical devices

\section{Introduction}

Tissue engineering approaches aim to provide damaged tissues with the most suitable conditions in order to regenerate and fully heal as soon as possible. Therefore, depending on the complexity of the tissue, there will be different limitations. In this review, we have focused on the cranio-maxillofacial structure, a region of particular interest due to the numerous dental procedures, oral cavity diseases and treatments, and cranial abnormalities including craniosynostosis, neoplasms, cleft-lip palate and other kinds of hypoplasias, among others [1-3]. In this sense, there are multiple zones within the maxillofacial structure that may act as reservoirs of potentially pathogenic bacterial organisms, which tend to cause infections when the tissues are damaged (e.g., oral cavity). Thus, when designing novel materials for cranio-maxillofacial tissue engineering, it is highly recommended to add antibacterial properties.

The prolonged use of antibiotics before, during, and after performing interventions at these zones is a concerning common practice in the clinical setting [3-6]. However, in recent decades, 
the world is becoming aware of the importance of misusing antibiotics, and the consequences it has provoked, like the apparition of multi-resistant bacterial strains. Predictions estimate that in 2050 the mortality caused by these resistant strains will be higher than that of cancer [7]. Therefore, it is essential to develop a strong research field focused on alternative approaches to conventional antibiotics. In this regard, the use of new bio-based materials derived from renewable feedstocks with intrinsic antibacterial activity might represent a strategical alternative for tissue engineering applications, limiting the environmental concern associated to the current demand for polymers and composites [8,9].

\subsection{Bio-Based Polymers}

Before discussing the numerous applications that these polymers could play in cranio-maxillofacial regeneration, it is essential to precisely define the term "bio-based polymer". In the literature, the terms bio-based polymers and biodegradable polymers have been extensively used. Both biodegradable and bio-based polymers are considered eco-friendly materials, and this has led to the frequent misconception of their correct interchangeability. However, there is a key difference between the two types of polymers.

On the one hand, biodegradable polymers are those susceptible to degradation by biological activity, with the degradation accompanied by a lowering of its molar mass [10]. In contrast, the "bio-based" adjective does not refer to the properties of the polymers, but to the raw material from which they are obtained, being bio-based polymers derived from renewable resources, including plants, bacteria or algae, among others [11].

In this sense, bio-based polymers can also be classified according to their degradability, with both biodegradable (e.g., polylactic acid, PLA) and non-biodegradable (e.g., bio-polyethylene) bio-based polymers. Similarly, not all biodegradable polymers are bio-based polymers (e.g., polycaprolactone, PCL) [12]. Thus, every polymer can be classified according to these two characteristics into four groups as summarized in Scheme 1 [13].

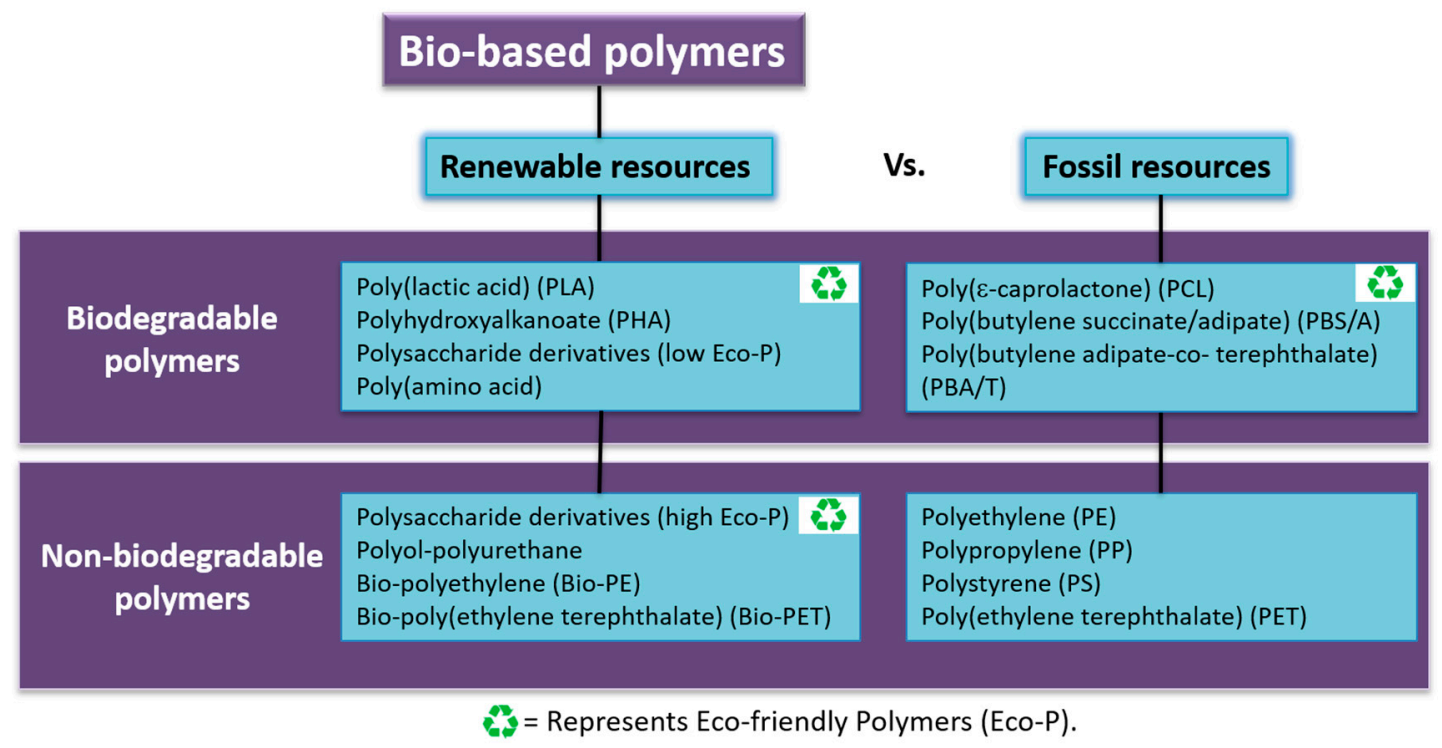

Scheme 1. Classification of bio-based polymers. Adapted from Iwata et al. 2015 [13], with permission from John Wiley and Sons and Copyright Clearance Center.

Bio-based polymers are considered eco-friendly materials based on the "carbon neutrality" concept. After being used, the non-biodegradable, bio-based polymers are burnt, generating carbon dioxide, which is then reconverted to biomass by photosynthetic organisms, and, therefore, they are being recycled. This fact may have enormous consequences for the economy. Due to the constant fluctuation 
in petroleum prices, it is imperative to find alternative resources in order to leverage the uncertainty of the oil market. However, nowadays, the bio-plastics market represents only about $1 \%$ of the 335 million tons of plastic that the world produces annually, and this production is continuously growing $[12,14]$.

For this reason, increasing efforts have been made in recent years to design polymeric materials from renewable resources in order to replace, to a higher extent, the current non-renewable fossil fuel-based products $[9,15]$. In this sense, the global bio-based-polymers market is expected to reach USD 9.6 billion by 2025, affecting this expansion to the biomedical sector too, an area which is not currently among the top five in the bio-based-polymers market [16]. The possibility to control the properties of the polymers by modulating different parameters such as their composition, thermal and mechanical stabilities or hydrophobicity/hydrophilicity ratio, allows us to produce a wide variety of polymer-based materials (e.g., hydrogels, scaffolds, membranes), which could be used with different applications for cranio-maxillofacial regeneration such as controlled drug-release, gene therapies and coatings, among others [9].

\subsection{Cranio-Maxillary Tissue Engineering}

In this review, we have focused on tissue regeneration, having limited our search to the cranio-maxillary region, a complex area which includes different structures such as the bones of the face (e.g., maxillary bones), the skull, dental organs and their surrounding tissues. In turn, all these structures are composed of both hard and soft tissues like bone, cartilage, epithelium, or periodontal tissues, thus presenting many pathologies which might require clinical intervention.

On the one hand, there are many congenital, genetic disorders and multiple anomalies that interfere with bone development in the area of the skull and maxillary bones, which are encompassed under the collective term "craniofacial syndromes". They are directly associated with the development of bone and cartilage, affecting the form and function of the head and face [17], and include those associated with the oral cavity too.

An illustrative example is the cleft lip/palate, a syndrome which occurs as a result of the non-fusion of the primary palate, causing a severe absence of bone in this area [2,18]. These orofacial cleft conditions have been estimated to have a global annual prevalence of 7.94 cases per 10,000 live births with high variances of treated patients across regions and countries causing a high economic impact worldwide [1,19-21]. In these cases, a replacement through autologous grafting would be required, but due to its invasiveness and high cost, there are other strategies like the use of hybrid scaffolds or composites which can replace the palatal, maxillary and the alveolar cleft defects [22].

On the other hand, there are multiple conditions which are not caused by a genetic malformation such as an alveolar atrophy, trauma-related pathological defects, odontogenic keratocysts, giant cell lesions, or ameloblastoma, among others. However, all these anomalies, and some clinical procedures (e.g., maxillary sinus elevation surgery), result in critical bone defects [2,23,24].

However, apart from the tissues' complexity, the most important issue regarding craniofacial syndromes and related dental procedures are the resident, pathogenic microorganisms found in these regions, and how they negatively influence the recovery of patients $[25,26]$. The microbiota of the nasal and oropharyngeal cavities is predominantly composed of Lactobacillus species and a variety of Gram-negative organisms such as Staphylococcus and Enterobacter species, among others, that can cause concomitant infections, resulting in severe medical pathologies like osteomyelitis or other chronic bacterial infections (e.g., periodontitis and peri-implantitis) [26,27]. For all these reasons, there is a clinical need to develop biomaterials that meet the demands of each area to achieve tissues regeneration while having antibacterial properties to avoid secondary bacterial infections [27]. In this sense, the most clinically applied systems in oro-cranio-facial regeneration are (Figure 1):

1. Membranes for Guided Tissue/Bone Regeneration. During bone-regenerative treatments, soft tissues of the oral cavity tend to proliferate too and can impede the correct restoration of the area. For this reason, it is necessary to employ a physical barrier (a membrane) to exclude 
the gingival epithelium and connective tissue ingrowth, while enhancing the formation of bone and/or periodontal tissues [28-31].

2. Scaffolds and Implanting Medical Devices for Soft and Hard Maxillofacial Tissues:

a. Hybrid scaffolds act as extracellular matrix substitutes, improving cell viability, attachment, proliferation and differentiation, as well as vascularization, host integration, and load bearing. They are mainly used for cranial and maxillary regenerative therapies like preventing oroantral fistulae or for treating maxillary peri-implantitis [32,33].

b. Dental implants are a common choice for substituting missing teeth due to the excellent mechanical and chemical properties of the employed alloys. However, the application of bacterial biofilms on their surfaces may affect their outcome. For this reason, it is necessary to use materials and composites as coatings to provide implants with antibacterial properties [34-36].

c. Hydrogels. Due to their unique properties, hydrogels are a perfect choice for filling irregular cavities during many clinical interventions such as maxillary sinus lift, replacement of bone structure caused by oroantral fistulae, maxillary peri-implantitis, sinusitis of zygomatic and bone defects of dental implant origin, among others [37,38].

d. Polymeric and Bioactive Glass-based composites are used to induce and conduct the mineralization of tissues in cranial and periodontal defects repair. In this regard, bioactive glasses (BGs) are mainly employed as bone substitutes in orthopaedics for maxillofacial reconstruction and as bioactive coatings in dental implants [39-42].

3. Cements are applied during the rehabilitation and placement of dental crowns, bridges, inlays, onlays or veneers, which are treatments where bacteria may be still present due to a partial removal of a caries or due to certain microleakage after cementing [43].

Thus, in summary, throughout this review we have highlighted the use of bio-based polymers, which by their own nature, or by chemical modifications of their structure, and/or by their combination with other substances, provide a useful antibacterial activity as well as the suitable conditions to develop the aforementioned systems for oro-cranio-facial regeneration.
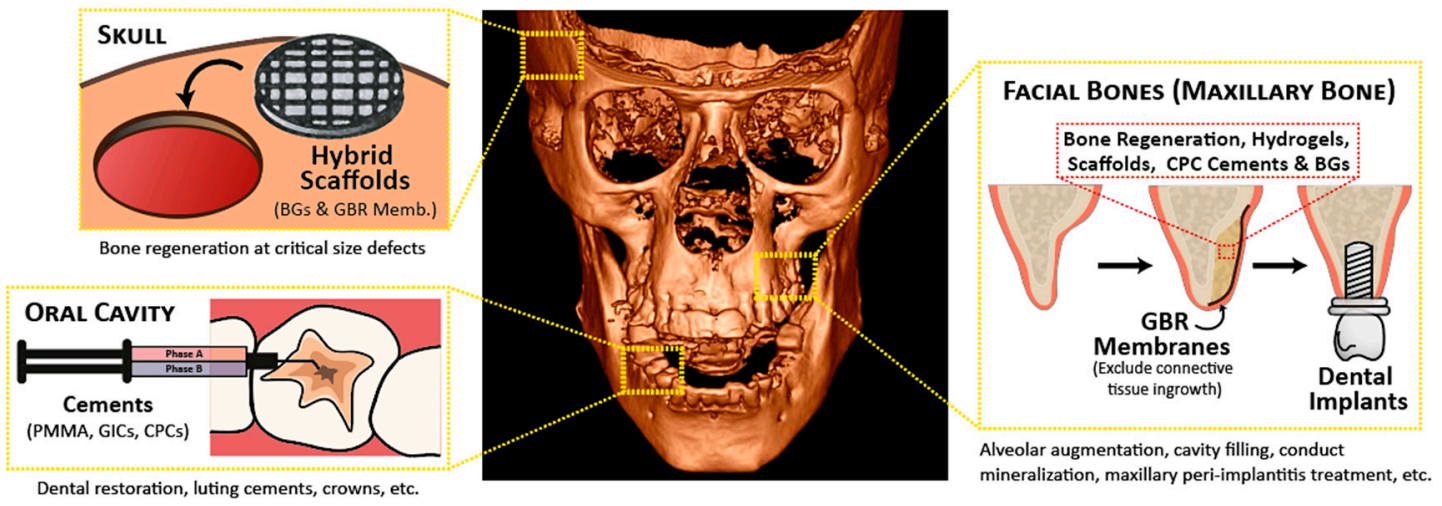

Figure 1. Most clinically applied systems in oro-cranio-facial regeneration and areas of interest, including the skull, facial bones (e.g., maxillary bone), and the oral cavity. Applications are shown below the boxes. Abbreviations: Bioactive glasses (BGs), calcium phosphate cements (CPCs) glass ionomer cements (GICs), guided bone regeneration membranes (GBR Memb.), polymethyl methacrylate cements (PMMA).

\section{Membranes for Guided Tissue/Bone Regeneration}

The use of guided tissue/bone regeneration (GTR/GBR) approaches has recently increased in the oral and maxillofacial fields, being widely used for the augmentation of alveolar bone in maxillofacial surgery or in the reconstruction of oral tissues such as during the placement of dental implants, or during 
the regeneration of periodontal and endodontic tissues. This procedure is based on the concept of employing a physical barrier (membrane) to exclude gingival epithelium and connective tissue ingrowth, while enhancing the formation of bone and/or periodontal tissues [28-31,44]. Regarding their design, different polymeric materials, bio-based or not, have been employed for GTR/GBR, including synthetic polymers like polytetrafluorethylene (PTFE) or aliphatic polyesters such as PLA, polygalacturonic acid (PGA) or PCL; and natural ones like collagen or alginate [29,45-53]. However, although these membranes are widely marketed today, they do not possess intrinsic antibacterial properties [31,54-57].

In this sense, during the past 20 years, chitosan has been one of the most attractive candidates for tissue regeneration due to its low cost, biocompatibility, appropriate degradation rate, and hemostatic activity, among other characteristics. This polysaccharide is obtained from the partial deacetylation of chitin, being mainly composed of D-glucosamine and partly of N-acetyl-D-glucosamine units. Moreover, this bio-based polymer has not only been reported to provide a better substrate for osteoblasts attachment and proliferation rather than for fibroblasts colonization, but also it inhibits some Gram-negative and Gram-positive bacterial infections such as Actinobacillus actinomycetemcomitans and Streptococcus mutans, making it a good candidate for maxillofacial GBR applications [46,58-60]. Nevertheless, there are several factors influencing its antibacterial properties like the molecular weight, degree of deacetylation and polymer concentration, as its bactericidal mechanism has not been completely elucidated yet [58,61-64].

Chitosan has been employed in different forms. For example, chitosan nanoparticles have been investigated due to their potential to adhere to mucosal surfaces for drug delivery purposes. It was reported that chitosan acted synergistically with chlorhexidine or minocycline in collagen membranes for periapical GTR [44,46,65], showing antibacterial properties as well as biocompatibility and barrier function against Enterococcus faecalis [44]. On the other hand, chitosan has been widely employed for GBR membranes blended with other polymers such as collagen, against $S$. mutans [66], and PCL and gelatin, against Escherichia coli and Staphylococcus aureus (Figure 2) [62]. As an alternative, Jin et al. recently studied a composite-membrane combining chitosan and silver particles, which they hypothesized could release silver ions from the fibers in a controlled manner in order to achieve enough antibacterial effects without affecting the biocompatibility of the material $[31,67]$.
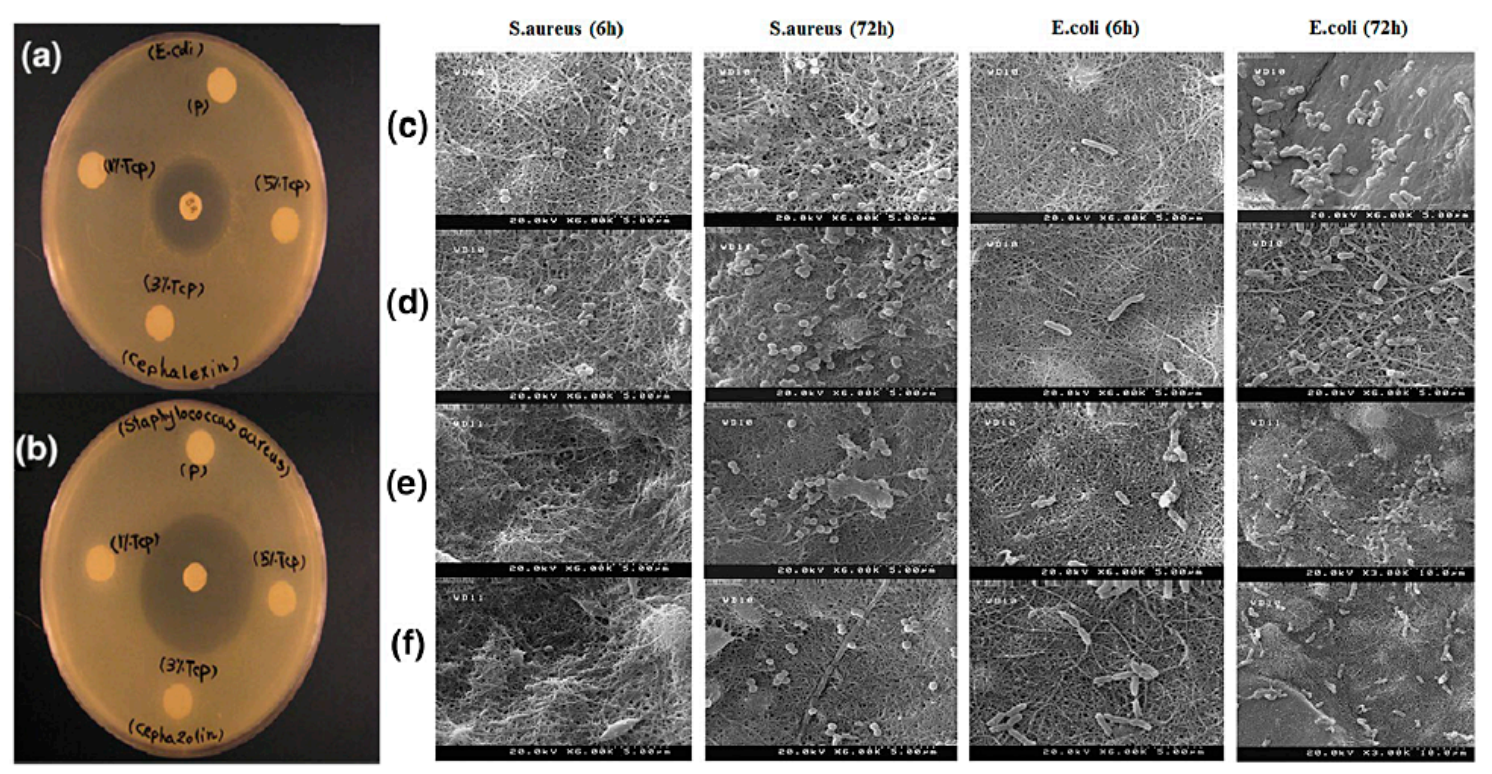

Figure 2. Antibacterial efficacies of the chitosan-polycaprolactone (PCL) samples against $S$. aureus and E. coli evaluated by zone of inhibition assay $(\mathbf{a}, \mathbf{b})$. Scanning electron micrographs of $S$. aureus and E. coli adhered on the samples after 6 and 72 h (c-f). Reproduced from Ezati et al. 2018 [62], with permission from Creative Commons CC BY International License. 
In the work carried out by Saarani et al., they described a triple-layered GBR membrane composed of poly(lactic-co-glycolic) acid (PLGA), nanoapatite and lauric acid [68]. This last component is a medium-length long-chain fatty acid which is present in coconut palm or milk. It is biocompatible, as it is found in human sebum as well, and it has been demonstrated to have antibacterial properties against different microorganisms. In this work, the authors showed that the antibacterial capacity of the studied GBR membrane could be enhanced by increasing the content of lauric acid in the composite [68].

\section{Scaffolds and Implanting Medical Devices for Soft and Hard Maxillofacial Tissues}

There are multiple conditions such as trauma, alveolar atrophy, pathological defects, maxillary sinus elevation or dental implantations that can cause gingival resorption and bone loss at the maxillofacial region, resulting in critical bone defects. Thus, the use of tissue engineering strategies is an alternative to tackle these problems $[23,69]$. Several synthetic and natural, bio-based polymeric scaffolds, including collagen, chitosan, PLA, polyhydroxybutyrate (PHB), or polyhydroxyalkanoates (PHAs)-based scaffolds, among others, have been investigated for generating human artificial tissues like the oral mucosa or maxillofacial bone $[23,70,71]$. Nevertheless, apart from promoting tissue regeneration, it is necessary to develop composite scaffolds and implantable devices with antimicrobial properties, or which are capable of loading drugs and antibiotics in order to prevent potential infections.

\subsection{Hybrid Scaffolds}

Scaffolds are three-dimensional constructs that act as a substitute of the extracellular matrix, providing a supporting structure for cell colonization, proliferation, and subsequent new tissue formation [72]. Several polymeric, composite materials have been clinically employed for cranial and maxillary regenerative therapies (e.g., collagen-based sponge grafting for preventing oroantral fistulae, maxillary peri-implantitis, sinusitis of zygomatic and bone defects of dental implant origin) [33].

Polyesters are the main biodegradable polymers which have received more attention due to their physical characteristics, revealing a wide range of properties, from rigid-brittle to flexible plastics. In this sense, the combination of different polymers like PCL, PHB or PLGA has demonstrated good features for repairing damaged human tissues, as well as for developing devices for drug-release purposes, including antibiotics [73,74]; or nanoparticles with antibacterial properties (Figure 3) [54,75,76]. In particular, PCL is a common choice for developing polymeric blends because of its low melting point, great mechanical properties and non-enzymatic degradation by hydrolysis. In contrast, it also presents some drawbacks such as its hydrophobicity, limited bioactivity and its neutral charge. For this reason, its combination with other bio-based polymers not only solves these limitations, but also the disadvantages of their counterparts. For instance, in chitosan/PCL blends, the former could supply a positive charge and biocompatibility, while the latter could enhance the poor mechanical properties of chitosan and control the overall degradation of the scaffold [77].

Recently, Ding et al. studied drug incorporation into organic/inorganic hybrid scaffolds in contrast to pure polymeric or ceramic ones, which are more common in the field. The group developed two hybrid scaffolds made of PHB/PCL, containing or not a sol-gel-derived silica, and loaded levofloxacin as a model antibiotic. Their studies shown that these scaffolds exhibited antibacterial action against both Gram-positive S. aureus and Gram-negative E. coli, while not affecting osteoblast viability. Moreover, the silica phase dissolution significantly increased the mineralization nodules after 4 weeks of culture, being the optimal choice for bone tissue regeneration [70]. In a similar way, Sarasam et al. synthesized two-dimensional membranes and three-dimensional porous scaffolds to evaluate the antibacterial properties of chitosan blended with PCL matrices in different configurations against two pathogens S. mutans and A. actinomycetemcomitans. This study indicated that chitosan impaired the proliferation of microorganisms on its surface despite a certain loss of a activity after its blending with PCL [76]. 

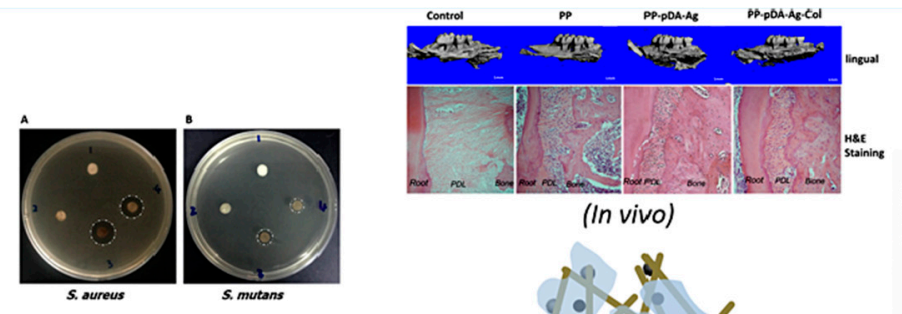

Bacterial inhibition
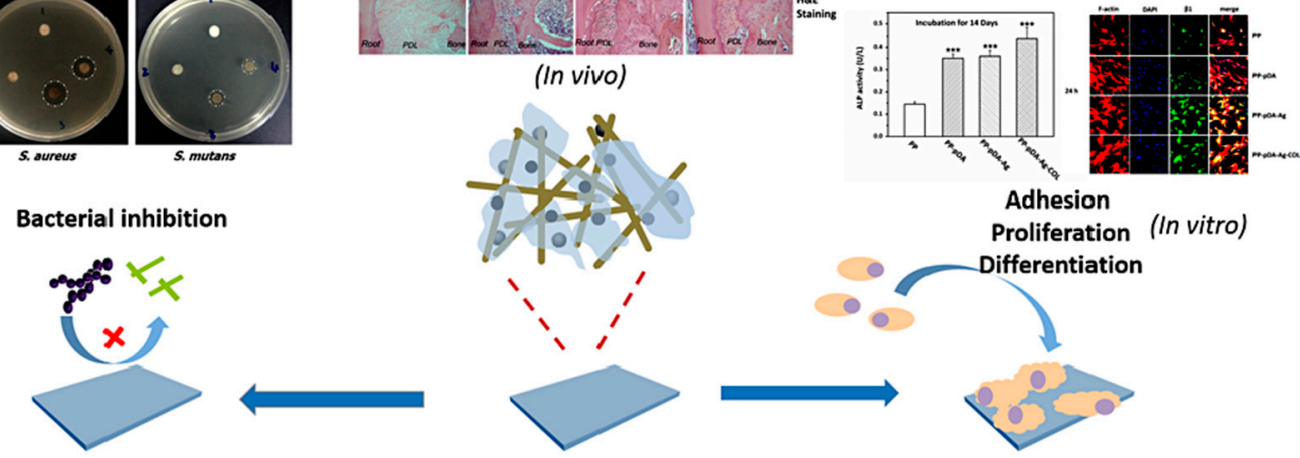

Adhesion Proliferation (In vitro)
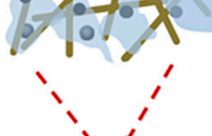

1,
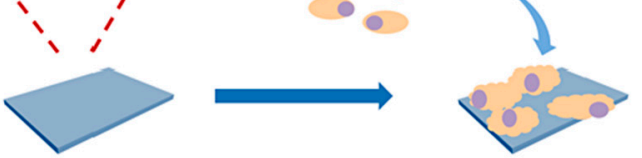

PP-PDA-Ag-COLI

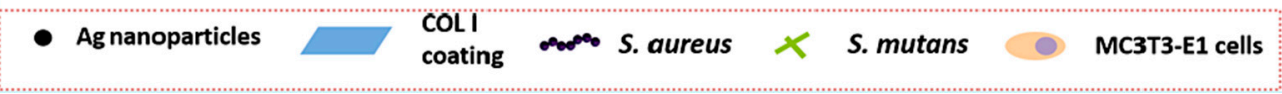

Figure 3. Biodegradable, synthetic scaffolds (poly(lactic-co-glycolic) acid (PLGA)/PCL blend (PP), silver-modified/collagen and polydopamine (pDA)) as materials used for the fabrication of oral and craniofacial guided tissue regeneration (GTR) materials. Reprinted with permission from Qian et al. 2019 [54], with permission from Copyright 2019 American Chemical Society.

The use of bio-based polymers has been widely investigated for the reconstruction of soft tissues such as palatal, gingival and periodontal tissues. Several studies have reported the clinical applicability of collagen-based scaffolds for oral soft tissue augmentation to support wound healing $[78,79]$. However, many of such studies have recommended the modification of collagen to improve its regenerative and antimicrobial potential [23].

On the other hand, the antibacterial activity of chitosan-based scaffolds has been investigated by several authors reporting chitosan as a perfect wound dressing candidate for the treatment of defects of the maxillofacial region such as palatal, gingival and periodontal wounds [80-84]. In this way, according to Ozmeriç et al., chitosan also seems to stimulate fibroblasts, and it could be considered as a biodegradable and non-toxic material, capable of activating macrophages and neutrophils, and, therefore, preventing infections, while accelerating wound healing. This could be particularly beneficial in the case of destructive diseases like periodontitis [80]. In addition, Park et al. recently developed a hydrophobically-modified glycol-chitosan nano-controlled system that was injected into critical-sized defects in palatal soft tissues of dogs, demonstrating that the use of these chitosan-based systems can promote the regeneration of oral soft tissue defects too [81].

\subsection{Dental Implants}

Titanium (Ti) implants constitute a globally accepted device in dental restoration for substituting missing teeth due to their excellent mechanical and chemical properties, their good corrosion resistance, and biocompatibility. However, some inevitable mechanical or biological complications such as mucositis, peri-implantitis, and marginal bone resorption can result from the apparition of bacterial biofilms on their surfaces [34-36]. In this sense, numerous approaches have been proposed to functionalize titanium surfaces by using anti-adhesive polymers to inhibit biofilm colonization [85]. For instance, polysaccharides such as chitosan and hyaluronic acid have been demonstrated to inhibit bacterial adhesion to titanium by interfering with surface linkage between titanium and the biofilm forming bacteria (Figure 4) [35,86-88]. The antibacterial effect resulting from the combined properties of these two polysaccharides, via reducing the hydrophobic interactions and van der Waals forming forces, diminished bacterial adhesion [35,89]. 


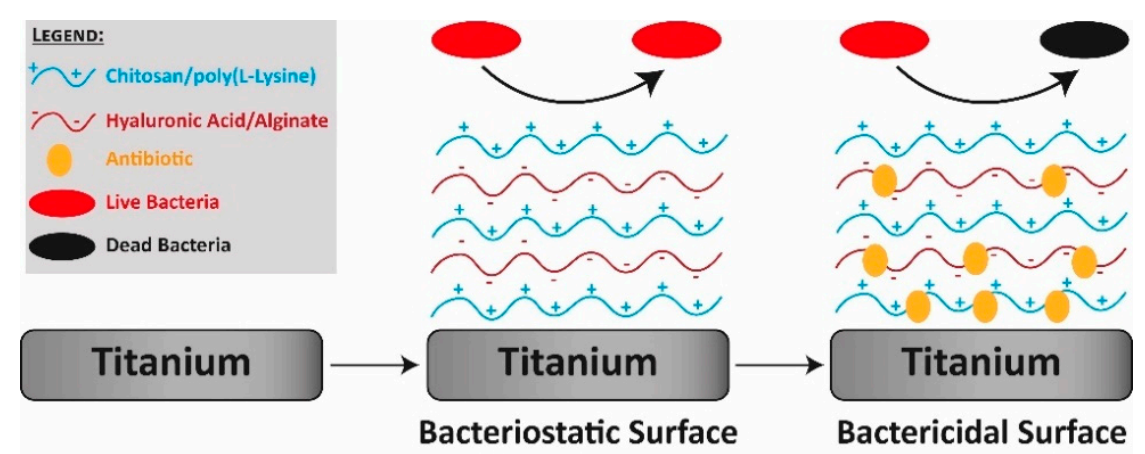

Figure 4. Layer by layer coating of polycationic and polyanionic polymers to make bacteriostatic surfaces. Reproduced and adapted from Chouirfa et al. 2019 [35], with permission from Elsevier.

Functionalization with bioactive compounds is another approach to avoid bacterial fixation, one of the greatest disadvantages of the coatings of dental implants [85]. For example, Pezzotti et al. incorporated silicon nitride into polyetheretherketone (PEEK), a polymeric biomaterial used for trauma, prosthodontics, maxillofacial, and cranial implants, demonstrating significant bacteriostatic properties against Gram-positive Staphylococcus epidermidis [90]. In this way, some composites of nanostructured coatings based on bio-based polymers have been investigated showing great potential. For example, Baghdan et al. used a nano spray-dried antibacterial coating consisting of biodegradable PLGA and norfloxacin against $E$. coli achieving a $99.83 \%$ reduction in the number of bacterial colonies [91]. In another approach, Divakar et al. tested the efficacy of silver-conjugated chitosan nanoparticles as a prospective coating material of titanium dental implants, reporting that the chitosan-based coating exhibited a high inhibitory effect on the growth of S. mutans and Pseudomonas gingivalis, inhibiting bacterial adhesion and reducing biofilm formation [36].

Looking to the future, the major challenge of these kinds of bio-based-polymeric coatings is the prevention of bacterial biofilm formation through antibacterial surface activity, while not affecting the viability of osteoblastic cells. For this reason, the need to study composite systems has increased in recent years, seeking the promotion of the proliferation and differentiation of native cells, while using antibacterial agents to prevent the development of infections [85].

\subsection{Hydrogels}

Hydrogels are water-swollen, polymeric materials that have been studied for bone and cartilage tissue engineering due to their potential use as a minimally invasive biomaterial for filling irregular cavities. For instance, they have been suggested in elevation treatments of the maxillary sinus floor [37,38], by using natural polymers like silk, collagen, hyaluronic acid, gelatin or chitosan with advantages such as controlling their degradability, versatile chemistry, impressive mechanical properties, low inflammatory profile and high antibacterial activities against S. aureus or Helicobacter pylori. In this regard, different authors have recently studied thermosensitive chitosan-based hydrogels for sealing and lubricating purposes in dental implantation systems, successfully testing their antibacterial ability against $E$. coli, S. aureus and P. gingivalis [34,92]. Furthermore, the use of hydrogels has been considered as an effective approach to combine both antibacterial efficacy and excellent osteoblastic cells responses, having great potential in ligament and bone regeneration, and, therefore, for maxillofacial regeneration [37,93-95].

\subsection{Polymeric and Bioactive Glass-Based Composites}

Bioactive glasses (BGs) are materials with the ability to induce and conduct the mineralization of tissues, which are currently widely employed in maxillofacial reconstruction, cranial and periodontal defects repair, alveolar ridge augmentation, as bone substitutes in orthopedics, and as bioactive coatings in dental implants, among other applications [39-42,96]. The incorporation of these glasses 
into various restorative dental materials has been recently investigated with the aim of providing bioactivity and antimicrobial properties against oral bacteria such as Streptococcus sanguis, S. mutans and Actinomyces viscosus [96].

Bioactive glass nanocomposites (58S-BG) consisting of $\mathrm{SiO}_{2}, \mathrm{CaO}$ and $\mathrm{P}_{2} \mathrm{O}_{5}$ have been widely applied for bone tissue engineering due to their excellent biocompatibility, bioactivity, antimicrobial activity and tight bonding between the dental implants and the surrounding bone [41,97]. Other examples include the BG-chitosan composite which was deposited on PEEK/BG layers, providing an antibacterial and bioactive coating [98], or a self-gelling pectin-BG composite, which was reported as an injectable composite with antibacterial activity [99]. In addition, some BGs have been incorporated into membranes along with bio-based polymers such as poly(3-hydroxybutyrate-co-3-hydroxyvalerate) (PHBV) to provide them with a favorable surface roughness, hydrophilicity and flexibility, but also to develop devices with potential applicability as multidrug carriers (e.g., antibacterial and/or antiosteoporotic drugs), making them promising candidates to be applied in GTR/GBR applications [100]. This has led to the study of composites based on BG and other natural polymers such as gelatin and collagen biomimetic electrospun fish collagen, which possess antibacterial activity against $S$. aureus and which could be used as a functional skin wound dressing [101].

\subsection{Other Approaches}

Flavonoids are phenolic compounds which have been studied because of their antioxidant, anti-inflammatory, and antimicrobial capacities. They are present in fruit and vegetables mostly as glycosides, but they can also appear in a free form as sulfates, esters, dimers or polymers. Indeed, some studies have reported antibacterial effects of different flavonoids such as quercitrin, galangin, chrysin and taxifolin against diverse bacteria like S. aureus, considering its use for periodontal applications [102-104].

In this regard, Gómez-Florit et al. studied the effect of different flavonoids on human gingival fibroblasts showing that quercitrin had the most promising biological effects due to its non-toxicity; its capacity of increasing collagen III $\alpha 1$ and decorin levels while decreasing the expression of profibrotic markers during wound healing and also its capacity for decreasing the bacterial growth rate [103]. For these reasons, it is expected that quercitrin might contribute to protect and recover the integrity of gingival tissue after injuries. In another study, quercitrin was found to increase mineralization, alkaline phosphatase activity and osteoblastic differentiation of human mesenchymal stem cells. These findings suggest that quercitrin might be a novel bioactive molecule with potential therapeutic effects for soft and hard tissue regeneration processes and could be used in its polymeric form for periodontal applications [103,104].

In another approach, Almaroof et al. reported the use of a polymerizable eugenol derivative to provide hydroxyapatite, $\mathrm{ZnO}_{2}$-containing, Bis-GMA/TEGDMA (2,2-bis [4-(2-hydroxy-3methacryloyloxypropyl)-phenyl] propane/tri-ethyleneglycol dimethacrylate) resin-based formulations with antibacterial properties. They found that the anchoring of the eugenyl-derivative onto the surfaces of the material exhibited an effective bacteriostatic activity against E. faecalis, S. mutans and Propionibacterium acnes (Figure 5) [105,106]. 
A)

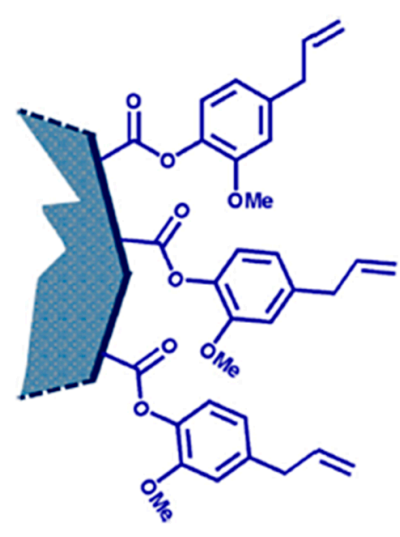

B)

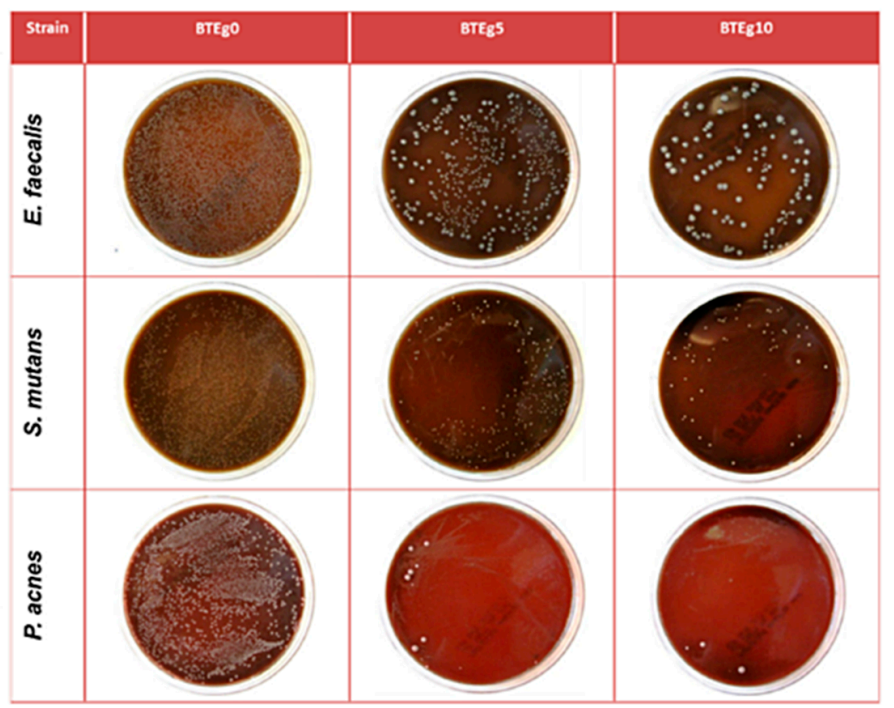

Figure 5. Schematic illustration of pendent eugenyl residues from the polymeric network on the surface of the composites (A), and images of composites surface antibacterial activity assay according to the ISO 22196:2007 after $24 \mathrm{~h}$ of incubation (B). Adapted from Almaroof et al. 2016 [105], with permission from Elsevier.

\section{Cements}

Cements are reconstructive materials based on self-curing components via an acid-base reaction or free radical polymerization, leading to cement curation. Self-curing cements can be classified according to their composition in three main categories: polymethyl methacrylate (PMMA)-based resins, glass ionomer cements (GICs) and calcium phosphate cements (CPCs).

\subsection{Polymethyl Methacrylate-Based Cements}

PMMA-based cements are composed of both a liquid monomer and a solid phase of PMMA and/or other co-polymers as powder. Polymerization occurs when amino and benzoyl-peroxide groups of each phase react, emitting high doses of energy in the form of heat, which in turn limits their applicability in great volumes. Moreover, the other major concern about these resins is their inert behavior, which often leads to bacterial colonization. For this reason, cement-soaking with antibacterial agents was one of the first ways to avoid infections. However, this approach resulted in a diminishment of the mechanical properties of the cements. In this sense, the use of bio-based polymers can fulfill these necessities via reinforcing the mechanical properties of antibacterial-soaked cements or using bio-based polymers with antibacterial properties. Tan et al., tested (in vivo) the effect of quaternized chitosan (hydroxypropyltrimethyl ammonium chloride chitosan, HACC)-loaded PMMA bone cement on methicillin-resistant S. aureus (MRSA)-infections of the tibial metaphysis in a rabbit model, infections which are specially difficult to overcome due to antibiotics resistance. By using this quaternized chitosan, they obtained much better antibacterial results in comparison to the gentamycin-loaded and the chitosan-loaded cements. Moreover, bone lysis, cyst formation and sequestral bone formation was observed in the control, gentamycin-loaded and chitosan-loaded cements while they were not in the HACC-loaded PMMA, obtaining the lowest histopathological scores among all the conditions [107].

Shi et al. studied (in vitro) the effect of loading chitosan and quaternary ammonium chitosannanoparticles into PMMA cements with, or without, additional gentamycin. On the one hand, they demonstrated that the addition of the nanoparticles did not alter the mechanical properties of the cement and provided antibacterial effects against S. aureus and S. epidermidis [108]. The best antibacterial results were achieved with the quaternary ammonium chitosan nanoparticles, which was in agreement with other authors, probably because of its higher surface density when compared to chitosan, as explained in [109]. 
In contrast, Wang et al. loaded chitosan hydrogels into PMMA cements obtaining antibacterial composites with good mechanical properties $[110,111]$. In a first work, they functionalized a PMMA-based commercial cement with a hydrogel of chitosan and poly(vinyl alcohol) (PVA) containing nano-sized hydroxyapatite and silver ions. The inclusion of hydrophilic hydrogels like that one within PMMA matrixes creates a porous structure which is beneficial for bone growth, upgrading a bioinert PMMA resin into a bioactive composite which could induce crystals formation. Moreover, the addition of nano-sized hydroxyapatite promoted the formation of a dense layer of apatite on the surfaces of the pores while silver ions provided the antibacterial properties (Figure 6) [111]. In a subsequent work, the authors loaded a quaternized chitosan derivative (HACC)-glycerophosphate hydrogel, which provided both mechanical, antibacterial and osteogenic properties to the cement, diminishing the number of components. Furthermore, it lowered the maximum temperature value of the setting reaction to less than $30^{\circ} \mathrm{C}$ while increasing the working time [110].

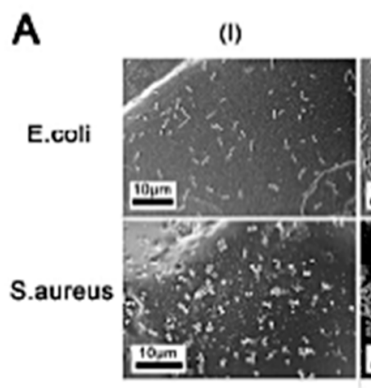

(II)

(III)

(IV)
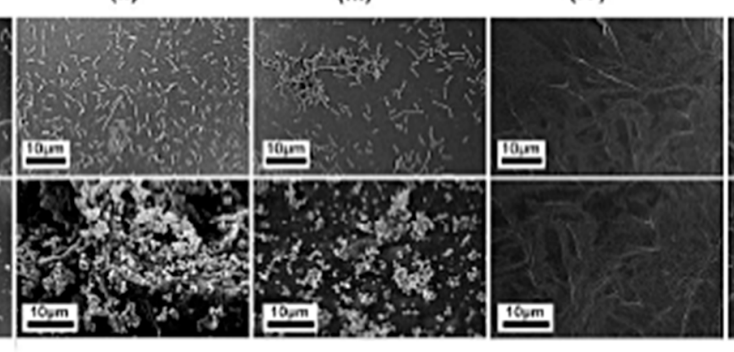

(v)

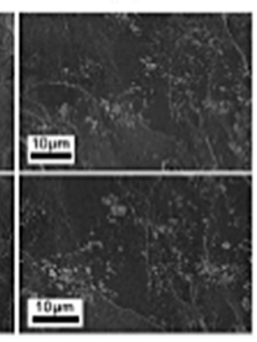

B

(I)

(II)

(III)

(IV)

(V)

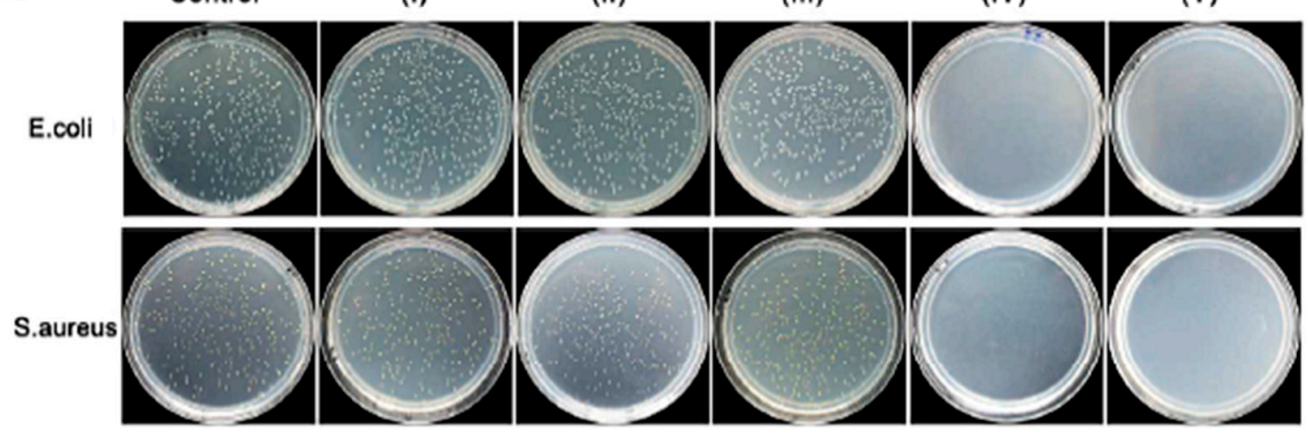

C

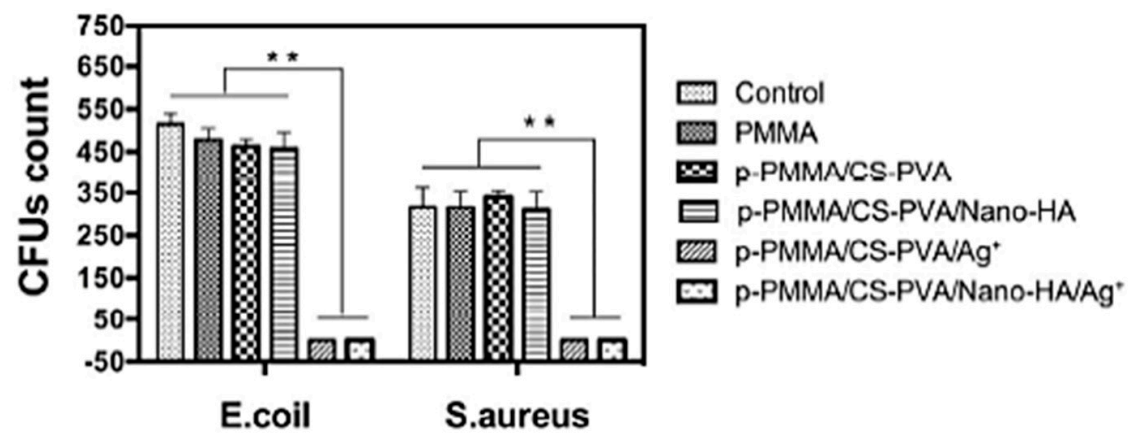

Figure 6. Contact bacteriostatic (A) and sustained-release bacteriostatic (B,C) of polymethyl methacrylate (PMMA)-based cements in E. coli and S. aureus: (I) PMMA cement; (II) PMMA cement functionalized with a hydrogel of chitosan and poly(vinyl alcohol) (PVA) (p-PMMA/CS-PVA); (III) PMMA cement functionalized with a hydrogel of chitosan and PVA containing nano-sized hydroxyapatite (p-PMMA/CS-PVA/Nano-HA); (IV) PMMA cement functionalized with a hydrogel of chitosan and PVA containing silver ions (p-PMMA/CS- PVA/Ag ${ }^{+}$); (V) PMMA cement functionalized with a hydrogel of chitosan and PVA containing nano-sized hydroxyapatite and silver ions (p-PMMA/CS-PVA/ Nano-HA $\left./ \mathrm{Ag}^{+}\right)$. Statistical significance: ${ }^{*} p<0.05$; ${ }^{* *} p<0.01$. Reproduced from Wang et al., 2016 [111], with permission from The Royal Society of Chemistry. 
Other authors have also used chitosan to induce porosity and roughness to the cement while incorporating additional elements to achieve the desired antibacterial properties. In this sense, Valencia Zapata et al. combined both chitosan and graphene oxide nanoparticles into an acrylic bone cement, which supported good cell viability of human osteoblasts while having both antibacterial and osteogenic properties [112,113]. Similarly, De Mori et al., designed a complex PMMA-based cement which was loaded with silver nanowires to achieve antibacterial properties; chitosan to achieve porosity, reduce the maximum setting temperature, and maintain appropriate mechanical properties; and methacryloyl chitosan to promote cross-linking with MMA, reducing the quantity of the monomer that is available for use [114].

\subsection{Glass Ionomer Cements}

In contrast to PMMA-based cements, glass ionomer cements (GICs) have an inherent antibacterial activity. Although the action mechanism is not fully understood, some hypotheses have been posed. On the one hand, the low $\mathrm{pH}$ of the cement during setting has been proposed as a suitable mechanism to prevent bacterial colonization during the intervention. On the other hand, fluoride and, in some cases, zinc released from GICs might also have an important role in the antibacterial nature of the cement. However, these properties are not enough to avoid the formation of $S$. mutans biofilms, leading to carious lesions. The addition of antibacterial compounds such as chlorhexidine or eugenol derivatives has also been investigated, but similar results to PMMA-based resins were obtained, with the mechanical properties reduced [115]. In this regard, the addition of bio-based polymers as modifiers to improve both the antibacterial and mechanical properties of commercial GICs is of great interest.

Different authors have demonstrated the effect of adding low quantities of chitosan to a commercial GIC [116,117]. On the one hand, there was an improvement in the mechanical properties of the GIC, which they attributed to the interaction via hydrogen bonds between the hydroxyl and acetamide groups of chitosan, and the hydroxyl groups of the inorganic particles with the carboxylic groups of poly(acrylic acid) (PAA), thus resulting in a stiffer network, and diminishing the interfacial tension among all the constituents. On the other hand, fluoride release from the GIC was catalyzed by chitosan due to the entropic gain associated to its release via chitosan adsorption with PAA, forming a polymeric network, which modulates the mechanical properties of the cement and its adhesion capacity to the enamel or the dentin.

Other authors have studied these effects in depth. For example, Ibrahim et al. added different concentrations of chitosan (from 5 to $50 \% v / v$ ) to a commercial GIC (GC Gold Label Glass Ionomer) and observed that dual effect: the reinforcement of mechanical properties, and the enhancement of its adhesion to the dentine. This effect was obtained only for those composites containing 5 and $10 \%$ chitosan, while concentrations over $25 \%$ negatively affected the micro-tensile bond strength, and, therefore, the adhesion to the dentin [118]. Similarly, Debnath et al. found an increment of $84 \%$ in the mean micro-shear bond strength of the $10 \% \mathrm{v} / \mathrm{v}$ chitosan-modified GIC to the enamel compared to the commercial one (Fuji IX) [119]. Regarding antibacterial properties, both articles assessed biofilm formation by S. mutans and found that $10 \%$ chitosan-modified GICs thinned the dense bacterial layer observed in control samples. Ibrahim et al. confirmed that higher concentrations of chitosan achieved better antibacterial results, although compromising the mechanical properties [118]. Thus, while above $10 \%$ chitosan there was a reduction in fluoride diffusion, the reported bactericidal effects seemed to be mainly caused by the presence of the polymer, and not by the ions. Moreover, a synergistic effect was found in both antibacterial and mechanical properties when combining chitosan and titanium-dioxide nano-powder [120]. Zhou et al. also analyzed whether gingival tissue could adhere to a root surface previously restored with a chitosan-modified GIC and, in agreement with the previous works, they reported the characteristic bimodal behavior of the mechanical properties when increasing the content of chitosan, and demonstrated that $2 \mathrm{wt} \%$ was the most cytocompatible dose 
of chitosan for the growth of human gingival fibroblast, due to the faster flow of fluoride ions to the medium, which consequently combined with $\mathrm{H}^{+}$, increasing the medium $\mathrm{pH}$ towards neutrality [121].

\subsection{Calcium Phosphate Composites}

Similarly to GIC cements, some authors have included chitosan into the liquid phase of calcium phosphate cements (CPCs) to create composite materials with antibacterial properties. Wu et al. reinforced CPCs with chitosan of different molecular weights or with HACC, and confirmed that the single addition of low-molecular weight chitosan $(30 \mathrm{kDa})$ and HACC avoided bacterial adhesion and biofilm formation without negatively affecting the cytocompatibility of the material [122]. A similar result was reported by Moncif et al., who combined a self-made apatite matrix with chitosan of high molecular weight $(250 \mathrm{kDa})$, obtaining a composite which showed better antibacterial results against S. aureus in comparison to S. epidermidis [123].

\section{Conclusions}

Cranio-maxillofacial area comprises various anatomical zones and tissues where different bacterial populations coexist within a delicate ecological balance. However, this microbiota contributes to the increased risk of bacterial infections when applying regenerative treatments. For this reason, the administration of adjuvants with antimicrobial properties is of particular interest to prevent the contamination at the local site. Thus, throughout this review, we have highlighted the potential applicability of bio-based polymers for these purposes (Appendix A); they are a promising, eco-friendly alternative that tackles antibacterial resistances and petroleum uncertainty, as well as limits the environmental concerns associated to the current demand for polymers and composites.

On the one hand, bio-based polymers present many features that make them perfect candidates to develop the wide variety of systems reviewed above such as their availability, versatility, adaptability and compatibility. Moreover, it is well-known that environmental factors (e.g., porosity, roughness, hydrophobicity) can play a pivotal role in different biological processes like allowing bacterial adhesion or promoting the proliferation of a preferred cell type. In this sense, bio-based polymers can be combined with other elements to modulate different parameters of the resulting material like the degradation rate (e.g., PCL blends), or to present cell-instructive sequences (e.g., RGD peptides).

On the other hand, the use of bio-based polymers presents some drawbacks too. For instance, among bio-based polymers, only chitosan and its quaternized derivative (HACC) have been reported to exert antibacterial properties on their own, and regarding chitosan, these properties depend on other physical parameters like its molecular weight. This leads to the second major disadvantage of the use of natural polymers: the batch-to-batch inhomogeneities. As bio-based polymers do not come from standardized processes, differences can be found among batches and results obtained with one batch might not be replicated by others if some parameters vary. For this reason, it is crucial to precisely physicochemically characterize this kind of natural raw material.

Nevertheless, future perspectives seem promising for the use of bio-based polymers for these indications. Firstly, because of the urgent need to replace conventional antibacterial treatments, many combinational approaches are being explored (e.g., nanoparticles, ions, graphene oxide, etc.). Moreover, research based on the polymerization of natural products or their derivatives may represent an interesting line to follow-up (e.g., quercitrin or eugenol). Finally, scientific multidisciplinarity may bring together some innovative approaches like the integration of gene or cell therapies, or the development of smart materials that respond to physiological signals, thus, strengthening the research on composites, which is often described as the favorite approach nowadays.

Author Contributions: Conceptualization, D.F.-V., M.M.-d.-C. and L.R.; writing-original draft preparation, D.F.-V., M.M.-d.-C. and G.C.-R.; writing-review and editing, all authors; supervision, L.R. All authors have read and agreed to the published version of the manuscript.

Funding: This work has been funded by the predoctoral program MICINN FPU18/04683 of the Spanish MICINN and by a postdoctoral program (711120) of CONACYT. 
Acknowledgments: Author Marcela Martin-del-Campo acknowledges to the "Especialidad en Odontología Estética, Cosmética, Restauradora e Implantología" program of the UASLP, México, for their support. The author Luis Rojo is a member of the SusPlast platform from the Spanish National Research Council (CSIC).

Conflicts of Interest: The authors declare no conflict of interest.

\section{Abbreviations}

$\begin{array}{ll}\text { BG } & \text { Bioactive glass } \\ \text { CPC } & \text { Calcium phosphate cement } \\ \text { CS } & \text { Chitosan } \\ \text { GIC } & \text { Glass ionomer cement } \\ \text { GTR/GBR } & \text { Guided tissue/bone regeneration } \\ \text { MRSA } & \text { Methicillin-resistant Staphylococcus aureus } \\ \text { Nano-HA } & \text { Nano-sized hydroxyapatite } \\ \text { PAA } & \text { Poly(acrylic acid) } \\ \text { PCL } & \text { Polycaprolactone } \\ \text { pDA } & \text { Polydopamine } \\ \text { PEEK } & \text { Polyetheretherketone } \\ \text { PGA } & \text { Polygalacturonic acid } \\ \text { PHAs } & \text { Polyhydroxyalkanoates } \\ \text { PHB } & \text { Polyhydroxybutyrate } \\ \text { PHBV } & \text { Poly(3-hydroxybutyrate-co-3-hydroxyvalerate) } \\ \text { PLA } & \text { Polylactic acid } \\ \text { PLGA } & \text { Poly(lactic-co-glycolic) acid } \\ \text { PMMA } & \text { Polymethyl methacrylate } \\ \text { PP } & \text { PLGA/PCL blend } \\ \text { PTFE } & \text { Polytetrafluorethylene } \\ \text { PVA } & \text { Poly(vinyl alcohol) } \\ \text { Ti } & \text { Titanium }\end{array}$




\section{Appendix A}

Table A1. Review's Overview: most clinically applied systems for cranio-maxillary regeneration, clinical applications, composition and references.

\begin{tabular}{|c|c|c|c|c|}
\hline \multicolumn{2}{|c|}{ Clinical System } & Clinical Applications & Bio-Based Polymer Employed & References \\
\hline \multirow{9}{*}{\multicolumn{2}{|c|}{$\begin{array}{c}\text { Membranes for Guided Tissue/Bone } \\
\text { Regeneration }\end{array}$}} & \multirow{9}{*}{$\begin{array}{l}\text { 1. Augmentation of alveolar bone, reconstruction of oral } \\
\text { tissues during the placement of dental implants, } \\
\text { or during the regeneration of periodontal and } \\
\text { endodontic tissues. } \\
\text { 2. Enhancing the formation of bone and/or } \\
\text { periodontal tissues }\end{array}$} & PTFE & {$[29,45,47,48]$} \\
\hline & & & PLA & {$[29,49]$} \\
\hline & & & PGA & {$[29,45]$} \\
\hline & & & Collagen & {$[51,52]$} \\
\hline & & & $\begin{array}{c}\text { Collagen (with chitosan, } \\
\text { chlorhexidine or minocycline) }\end{array}$ & {$[29,44,46,56,57,65,101]$} \\
\hline & & & $\begin{array}{l}\text { Chitosan (with chlorhexidine, } \\
\text { minocycline or collagen) }\end{array}$ & {$[44,58-60,101,111]$} \\
\hline & & & Chitosan (with silver particles) & {$[31,67]$} \\
\hline & & & $\begin{array}{c}\text { PLGA (with nanoapatite and } \\
\text { lauric acid) }\end{array}$ & {$[53,68]$} \\
\hline & & & Gelatin (with PCL) & [62] \\
\hline \multirow{6}{*}{$\begin{array}{c}\text { Scaffolds and Implanting } \\
\text { Medical Devices for Soft } \\
\text { and Hard } \\
\text { Maxillofacial Tissues }\end{array}$} & \multirow{6}{*}{ Hybrid Scaffolds } & \multirow{6}{*}{$\begin{array}{l}\text { 1. Sponge grafting for preventing oroantral fistulae, } \\
\text { maxillary peri-implantitis, sinusitis of zygomatic and } \\
\text { bone defects of dental implant. } \\
\text { 2. Scaffolds for oral soft tissue (such as palatal, gingival } \\
\text { and periodontal tissues). } \\
\text { 3. Augmentation to support wound healing. }\end{array}$} & PHB/PCL & {$[54,70,73-76]$} \\
\hline & & & $\begin{array}{c}\text { PLGA (with PCL, } \\
\text { silver-modified/collagen) }\end{array}$ & [54] \\
\hline & & & Collagen & {$[23,33,54,78,79]$} \\
\hline & & & Silver-modified/collagen & {$[80,81]$} \\
\hline & & & Chitosan & [80-84] \\
\hline & & & Chitosan/PCL & [76] \\
\hline \multirow{5}{*}{$\begin{array}{l}\text { Scaffolds and Implanting } \\
\text { Medical Devices for Soft } \\
\text { and Hard } \\
\text { Maxillofacial Tissues }\end{array}$} & \multirow{5}{*}{ Dental Implants } & \multirow{5}{*}{ Device in dental restoration for substituting missing teeth } & Chitosan & {$[35,36,86-88]$} \\
\hline & & & Chitosan and Hyaluronic Acid & {$[35,89]$} \\
\hline & & & $\begin{array}{c}\text { Silver-conjugated chitosan } \\
\text { nanoparticles }\end{array}$ & {$[36]$} \\
\hline & & & PEEK & [90] \\
\hline & & & PLGA (with norfloxacin) & [91] \\
\hline
\end{tabular}


Table A1. Cont.

\begin{tabular}{|c|c|c|c|c|}
\hline Clinical Sy & & Clinical Applications & Bio-Based Polymer Employed & References \\
\hline \multirow{8}{*}{$\begin{array}{l}\text { Scaffolds and Implanting } \\
\text { Medical Devices for Soft } \\
\text { and Hard } \\
\text { Maxillofacial Tissues }\end{array}$} & Hydrogels & $\begin{array}{l}\text { 1. Filling irregular cavities (bone and cartilage } \\
\text { tissue engineering). } \\
\text { 2. Elevation treatments of the maxillary sinus. } \\
\text { 3. Ligament and bone regeneration in maxillofacial } \\
\text { floor regeneration. }\end{array}$ & Chitosan & {$[34,92]$} \\
\hline & \multirow{5}{*}{$\begin{array}{l}\text { Polymeric and } \\
\text { Bioactive } \\
\text { Glass-based } \\
\text { composites }\end{array}$} & \multirow{5}{*}{$\begin{array}{l}\text { 1. To induce and conduct the mineralization of tissues in } \\
\text { maxillofacial reconstruction, cranial and periodontal } \\
\text { defects repair, alveolar ridge augmentation. } \\
\text { 2. Bone substitute in orthopedics. } \\
\text { 3. Bioactive coatings in dental implants. } \\
\text { 4. Incorporation into various restorative dental materials. }\end{array}$} & Chitosan (with BG) & [98] \\
\hline & & & PEEK (with BG) & [98] \\
\hline & & & Self-gelling pectin (with BG) & {$[99]$} \\
\hline & & & PHBV & [100] \\
\hline & & & Gelatin and Collagen & [101] \\
\hline & \multirow[b]{2}{*}{$\begin{array}{c}\text { Other } \\
\text { Approaches }\end{array}$} & \multirow{2}{*}{$\begin{array}{l}\text { Novel bioactive molecules with potential therapeutic } \\
\text { effects for soft and hard tissue regeneration processes and } \\
\text { periodontal applications }\end{array}$} & Quercitrin & {$[103,104]$} \\
\hline & & & $\begin{array}{l}\text { Eugenol derivative (with } \\
\text { hydroxyapatite, } \mathrm{ZnO}_{2} \text {-containing } \\
\text { Bis-GMA/TEGDMA) }\end{array}$ & {$[105,106]$} \\
\hline \multirow{7}{*}{ Cements } & \multirow{4}{*}{$\begin{array}{l}\text { PMMA-based } \\
\text { cements }\end{array}$} & \multirow{4}{*}{$\begin{array}{l}\text { Standard vehicles for loading antibiotics used in } \\
\text { maxillary orthopedics. }\end{array}$} & Chitosan & [112-114] \\
\hline & & & Chitosan hydrogels (with silver ions) & {$[110,111]$} \\
\hline & & & Quaternized chitosan (HACC) & [107] \\
\hline & & & Chitosan and HACC nanoparticles & {$[108,109]$} \\
\hline & \multirow[b]{2}{*}{$\begin{array}{l}\text { Glass Ionomer } \\
\text { Cements }\end{array}$} & \multirow{2}{*}{$\begin{array}{l}\text { 1. Applied during the rehabilitation and placement of } \\
\text { dental crowns, bridges, inlays, onlays or veneers. } \\
\text { 2. Standard vehicle for loading antibiotics in maxillary } \\
\text { orthopedics treatment. }\end{array}$} & Chitosan & {$[116-119,121]$} \\
\hline & & & Chitosan (with $\mathrm{TiO}_{2}$ nano-powder) & [120] \\
\hline & $\begin{array}{l}\text { Calcium } \\
\text { Phosphate } \\
\text { Cements }\end{array}$ & $\begin{array}{l}\text { 1. Bone fillers for fixating orthopedics and } \\
\text { dental implants. } \\
\text { 2. To avoid movements between the prosthesis and bone, } \\
\text { being applied as an interface between both. } \\
\text { 3. Performing osteoconductive actions in fractures and } \\
\text { bone defects. }\end{array}$ & Chitosan & {$[122,123]$} \\
\hline
\end{tabular}




\section{References}

1. Buchanan, E.P.; Xue, A.S.; Hollier, L.H. Craniofacial syndromes. Plast. Reconstr. Surg. 2014, 134, 128e-153e. [CrossRef]

2. Martín-Del-Campo, M.; Rosales-Ibañez, R.; Rojo, L. Biomaterials for cleft lip and palate regeneration. Int. J. Mol. Sci. 2019, 20, 2176. [CrossRef]

3. Heggie, A.A. Craniofacial disorders. Aust. Dent. J. 2018, 63, S58-S68. [CrossRef]

4. Steinberg, B.; Caccamese, J.; Costello, B.J.; Woerner, J. Cleft and Craniofacial Surgery. J. Oral Maxillofac. Surg. 2017, 75, e126-e150. [CrossRef]

5. Reddy, R.R.; Reddy, S.G.; Banala, B.; Bronkhorst, E.M.; Kummer, A.W.; Kuijpers-Jagtman, A.M.; Bergé, S.J. Placement of an antibiotic oral pack on the hard palate after primary cleft palatoplasty: A randomized controlled trial into the effect on fistula rates. Clin. Oral Investig. 2018, 22, 1953-1958. [CrossRef]

6. Straccia, M.C.; D'Ayala, G.G.; Romano, I.; Oliva, A.; Laurienzo, P. Alginate hydrogels coated with chitosan for wound dressing. Mar. Drugs 2015, 13, 2890-2908. [CrossRef]

7. O'Neill, J. Antimicrobial Resistance: Tackling a Crisis for The Health and Wealth of Nations; Review on Antimicrobial Resistance: London, UK, 2014.

8. Quirino, R.L.; Garrison, T.F.; Kessler, M.R. Matrices from vegetable oils, cashew nut shell liquid, and other relevant systems for biocomposite applications. Green Chem. 2014, 16, 1700-1715. [CrossRef]

9. Garrison, T.F.; Murawski, A.; Quirino, R.L. Bio-based polymers with potential for biodegradability. Polymers 2016, 8, 262. [CrossRef]

10. Horie, K.; Barón, M.; Fox, R.B.; He, J.; Hess, M.; Kahovec, J.; Kitayama, T.; Kubisa, P.; Maréchal, E.; Mormann, W.; et al. Definitions of terms relating to reactions of polymers and to functional polymeric materials: (IUPAC Recommendations 2003). Pure Appl. Chem. 2004, 76, 889-906. [CrossRef]

11. Yang, E.; Miao, S.; Zhong, J.; Zhang, Z.; Mills, D.K.; Zhang, L.G. Bio-Based Polymers for 3D Printing of Bioscaffolds. Polym. Rev. 2018, 58, 668-687. [CrossRef]

12. Babu, R.P.; O'Connor, K.; Seeram, R. Current progress on bio-based polymers and their future trends. Prog. Biomater. 2013, 2, 8. [CrossRef]

13. Iwata, T. Biodegradable and bio-based polymers: Future prospects of eco-friendly plastics. Angew. Chem. Int. Ed. 2015, 54, 3210-3215. [CrossRef]

14. Muñoz-Bonilla, A.; Echeverria, C.; Sonseca, Á.; Arrieta, M.P.; Fernández-García, M. Bio-based polymers with antimicrobial properties towards sustainable development. Materials 2019, 12, 641. [CrossRef]

15. Capellán-Pérez, I.; Mediavilla, M.; de Castro, C.; Carpintero, Ó.; Miguel, L.J. Fossil fuel depletion and socio-economic scenarios: An integrated approach. Energy 2014, 77, 641-666. [CrossRef]

16. Research and Markets Global Bio-Based Polymer Market (2019-2025). Available online: https:// www.researchandmarkets.com/reports/4837061/global-bio-based-polymer-market-2019-2025 (accessed on 15 November 2020).

17. Lewyllie, A.; De Llano-Pérula, M.C.; Verdonck, A.; Willems, G. Three-dimensional imaging of soft and hard facial tissues in patients with craniofacial syndromes: A systematic review of methodological quality. Dentomaxillofac. Radiol. 2018, 47. [CrossRef] [PubMed]

18. Moreau, J.L.; Caccamese, J.F.; Coletti, D.P.; Sauk, J.J.; Fisher, J.P. Tissue Engineering Solutions for Cleft Palates. J. Oral Maxillofac. Surg. 2007, 65, 2503-2511. [CrossRef]

19. Massenburg, B.B.; Riesel, J.N.; Hughes, C.D.; Meara, J.G. Global Cleft Lip and Palate Care: A Brief Review. Cleft Lip Palate Treat. 2018, 15-23. [CrossRef]

20. Jones, K.L.; Jones, M.C.; del Campo, M. Facial Defects as Major Feature. In Smith's Recognizable Patterns of Human Malformation, 7th ed.; Saunders: Yonkers, NY, USA, 2014; p. 1016. ISBN 9781455738113.

21. Hamze, H.; Mengiste, A.; Carter, J. The impact and cost-effectiveness of the amref health Africa-smile train cleft lip and palate surgical repair programme in eastern and central Africa. Pan Afr. Med. J. 2017, 28, 1-12. [CrossRef]

22. Seifeldin, S.A. Is alveolar cleft reconstruction still controversial? (Review of literature). Saudi Dent. J. 2015, 28, 3-11. [CrossRef]

23. Hatayama, T.; Nakada, A.; Nakamura, H.; Mariko, W.; Tsujimoto, G.; Nakamura, T. Regeneration of gingival tissue using in situ tissue engineering with collagen scaffold. Oral Surg. Oral Med. Oral Pathol. Oral Radiol. 2017, 124, 348-354. [CrossRef] 
24. Peacock, Z.S. Controversies in Oral and Maxillofacial Pathology. Oral Maxillofac. Surg. Clin. N. Am. 2017, 29, 475-486. [CrossRef]

25. Roode, G.J.; Bütow, K.W.; Naidoo, S. Preoperative evaluation of micro-organisms in non-operated cleft in soft palate: Impact on use of antibiotics. Br. J. Oral Maxillofac. Surg. 2017, 55, 127-131. [CrossRef]

26. Cocco, J.F.; Antonetti, J.W.; Burns, J.L.; Heggers, J.P.; Blackwell, S.J. Characterization of the nasal, sublingual, and oropharyngeal mucosa microbiota in cleft lip and palate individuals before and after surgical repair. Cleft Palate-Craniofac. J. 2010, 47, 151-155. [CrossRef]

27. Lu, H.; Liu, Y.; Guo, J.; Wu, H.; Wang, J.; Wu, G. Biomaterials with antibacterial and osteoinductive properties to repair infected bone defects. Int. J. Mol. Sci. 2016, 17, 334. [CrossRef]

28. Caballé-Serrano, J.; Sawada, K.; Miron, R.J.; Bosshardt, D.D.; Buser, D.; Gruber, R. Collagen barrier membranes adsorb growth factors liberated from autogenous bone chips. Clin. Oral Implants Res. 2017, 28, $236-241$. [CrossRef]

29. Caballé-Serrano, J.; Munar-Frau, A.; Ortiz-Puigpelat, O.; Soto-Penaloza, D.; Peñarrocha, M.; HernándezAlfaro, F. On the search of the ideal barrier membrane for guided bone regeneration. J. Clin. Exp. Dent. 2018, 10, e477-e483. [CrossRef]

30. Dimitriou, R.; Jones, E.; McGonagle, D.; Giannoudis, P.V. Bone regeneration: Current concepts and future directions. BMC Med. 2011, 9, 66. [CrossRef]

31. Jin, S.; Li, J.; Wang, J.; Jiang, J.; Zuo, Y.; Li, Y.; Yang, F. Electrospun silver ion-loaded calcium phosphate/ chitosan antibacterial composite fibrous membranes for guided bone regeneration. Int. J. Nanomed. 2018, 13, 4591-4605. [CrossRef]

32. Roseti, L.; Parisi, V.; Petretta, M.; Cavallo, C.; Desando, G.; Bartolotti, I.; Grigolo, B. Scaffolds for Bone Tissue Engineering: State of the art and new perspectives. Mater. Sci. Eng. C 2017, 78, 1246-1262. [CrossRef]

33. Jensen, O.T.; Adams, M.; Cottam, J.R.; Ringeman, J. Occult Peri-implant Oroantral Fistulae: Posterior Maxillary Peri-implantitis/Sinusitis of Zygomatic or Dental Implant Origin. Treatment and Prevention with Bone Morphogenetic Protein-2/Absorbable Collagen Sponge Sinus Grafting. Int. J. Oral Maxillofac. Implants 2013, 28, e512-e520. [CrossRef]

34. Cao, X.; Cai, X.; Chen, R.; Zhang, H.; Jiang, T.; Wang, Y. A thermosensitive chitosan-based hydrogel for sealing and lubricating purposes in dental implant system. Clin. Implant Dent. Relat. Res. 2019, 21, 324-335. [CrossRef]

35. Chouirfa, H.; Bouloussa, H.; Migonney, V.; Falentin-Daudré, C. Review of titanium surface modification techniques and coatings for antibacterial applications. Acta Biomater. 2019, 83, 37-54. [CrossRef]

36. Divakar, D.D.; Jastaniyah, N.T.; Altamimi, H.G.; Alnakhli, Y.O.; Muzaheed; Alkheraif, A.A.; Haleem, S. Enhanced antimicrobial activity of naturally derived bioactive molecule chitosan conjugated silver nanoparticle against dental implant pathogens. Int. J. Biol. Macromol. 2018, 108, 790-797. [CrossRef]

37. Zhang, W.; Wang, X.; Wang, S.; Zhao, J.; Xu, L.; Zhu, C.; Zeng, D.; Chen, J.; Zhang, Z.; Kaplan, D.L.; et al. The use of injectable sonication-induced silk hydrogel for VEGF 165 and BMP-2 delivery for elevation of the maxillary sinus floor. Biomaterials 2011, 32, 9415-9424. [CrossRef]

38. Lee, K.Y.; Mooney, D.J. Hydrogels for tissue engineering. Chem. Rev. 2001, 101, 1869-1879. [CrossRef]

39. Deepa, V.; Ahamed, S.; Sathish, E.; Meyappan, R.; Satheesh Kumar, K.; Narayana, S. Remineralization efficiency of bioactive glass on artificially induced carious lesion an in-vitro study. J. Indian Soc. Pedod. Prev. Dent. 2014, 32, 19. [CrossRef]

40. Allan, I.; Newman, H.; Wilson, M. Antibacterial activity of particulate Bioglass ${ }^{\circledR}$ against supra- and subgingival bacteria. Biomaterials 2001, 22, 1683-1687. [CrossRef]

41. Mokhtari, H.; Ghasemi, Z.; Kharaziha, M.; Karimzadeh, F.; Alihosseini, F. Chitosan-58S bioactive glass nanocomposite coatings on TiO 2 nanotube: Structural and biological properties. Appl. Surf. Sci. 2018, 441, 138-149. [CrossRef]

42. Silva-Herzog Rivera, D.; Pozos-Guillen, A.; Aragón-Piña, A.; Cerda-Cristerna, B.I.; Masuoka-Ito, D.; Sánchez-Vargas, L.O. Glass coatings to enhance the interfacial bond strength between veneering ceramic and zirconia. Odontology 2020, 108, 415-423. [CrossRef]

43. Daugela, P.; Oziunas, R.; Zekonis, G. Antibacterial potential of contemporary dental luting cements. Stomatol. Balt. Dent. Maxillofac. J. 2008, 10, 16-21. 
44. Barreras, U.S.; Méndez, F.T.; Martínez, R.E.M.; Valencia, C.S.; Rodríguez, P.R.M.; Rodríguez, J.P.L. Chitosan nanoparticles enhance the antibacterial activity of chlorhexidine in collagen membranes used for periapical guided tissue regeneration. Mater. Sci. Eng. C 2016, 58, 1182-1187. [CrossRef] [PubMed]

45. Elgali, I.; Turri, A.; Xia, W.; Norlindh, B.; Johansson, A.; Dahlin, C.; Thomsen, P.; Omar, O. Guided bone regeneration using resorbable membrane and different bone substitutes: Early histological and molecular events. Acta Biomater. 2016, 29, 409-423. [CrossRef] [PubMed]

46. Wang, J.; Wang, L.; Zhou, Z.; Lai, H.; Xu, P.; Liao, L.; Wei, J. Biodegradable polymer membranes applied in guided bone/tissue regeneration: A review. Polymers 2016, 8, 115. [CrossRef] [PubMed]

47. Kaushal, S.; Kumar, A.; Khan, M.A.; Lal, N. Comparative study of nonabsorbable and absorbable barrier membranes in periodontal osseous defects by guided tissue regeneration. J. Oral Biol. Craniofac. Res. 2016, 6, 111-117. [CrossRef] [PubMed]

48. Rakhmatia, Y.D.; Ayukawa, Y.; Furuhashi, A.; Koyano, K. Current barrier membranes: Titanium mesh and other membranes for guided bone regeneration in dental applications. J. Prosthodont. Res. 2013, 57, 3-14. [CrossRef]

49. Won, J.Y.; Park, C.Y.; Bae, J.H.; Ahn, G.; Kim, C.; Lim, D.H.; Cho, D.W.; Yun, W.S.; Shim, J.H.; Huh, J.B. Evaluation of 3D printed PCL/PLGA/ $\beta$-TCP versus collagen membranes for guided bone regeneration in a beagle implant model. Biomed. Mater. 2016, 11, 055013. [CrossRef]

50. Liu, J.; Sheha, H.; Fu, Y.; Giegengack, M.; Tseng, S.C.G. Oral Mucosal Graft with Amniotic Membrane Transplantation for Total Limbal Stem Cell Deficiency. Am. J. Ophthalmol. 2011, 152, 739-747. [CrossRef]

51. Barbeck, M.; Lorenz, J.; Kubesch, A.; Bohm, N.; Booms, P.; Choukroun, J.; Sader, R.; Kirkpatrick, C.J.; Ghanaati, S. Porcine dermis-derived collagen membranes induce implantation bed vascularization via multinucleated giant cells: A physiological reaction? J. Oral Implantol. 2015, 41, e238-e251. [CrossRef]

52. Wessing, B.; Urban, I.; Montero, E.; Zechner, W.; Hof, M.; Alández Chamorro, J.; Alández Martin, N.; Polizzi, G.; Meloni, S.; Sanz, M. A multicenter randomized controlled clinical trial using a new resorbable non-cross-linked collagen membrane for guided bone regeneration at dehisced single implant sites: Interim results of a bone augmentation procedure. Clin. Oral Implants Res. 2017, 28, e218-e226. [CrossRef]

53. Hoornaert, A.; D'Arros, C.; Heymann, M.F.; Layrolle, P. Biocompatibility, resorption and biofunctionality of a new synthetic biodegradable membrane for guided bone regeneration. Biomed. Mater. 2016, 11, 45012. [CrossRef]

54. Qian, Y.; Zhou, X.; Zhang, F.; Diekwisch, T.G.H.; Luan, X.; Yang, J. Triple PLGA/PCL Scaffold Modification including Silver Impregnation, Collagen Coating, and Electrospinning Significantly Improve Biocompatibility, Antimicrobial, and Osteogenic Properties for Orofacial Tissue Regeneration. ACS Appl. Mater. Interfaces 2019, 11, 37381-37396. [CrossRef]

55. Wu, G.; Deng, H.; Jiang, T.; Tu, H.; Chen, J.; Zhan, Y.; Wang, Y.; Ma, X. Regulating the gaps between folds on the surface of silk fibroin membranes via LBL deposition for improving their biomedical properties. Colloids Surf. B Biointerfaces 2017, 154, 228-238. [CrossRef]

56. Lee, S.B.; Kwon, J.S.; Lee, Y.K.; Kim, K.M.; Kim, K.N. Bioactivity and mechanical properties of collagen composite membranes reinforced by chitosan and $\beta$-tricalcium phosphate. J. Biomed. Mater. Res. Part B Appl. Biomater. 2012, 100 B, 1935-1942. [CrossRef]

57. Lotfi, G.; Shokrgozar, M.A.; Mofid, R.; Abbas, F.M.; Ghanavati, F.; Baghban, A.A.; Yavari, S.K.; Pajoumshariati, S. Biological Evaluation (In Vitro and In Vivo) of Bilayered Collagenous Coated (Nano Electrospun and Solid Wall) Chitosan Membrane for Periodontal Guided Bone Regeneration. Ann. Biomed. Eng. 2016, 44, 2132-2144. [CrossRef] [PubMed]

58. Chen, Y.H.; Tai, H.Y.; Fu, E.; Don, T.M. Guided bone regeneration activity of different calcium phosphate/ chitosan hybrid membranes. Int. J. Biol. Macromol. 2019, 126, 159-169. [CrossRef] [PubMed]

59. Shue, L.; Yufeng, Z.; Mony, U. Biomaterials for periodontal regeneration: A review of ceramics and polymers. Biomatter 2012, 2, 271-277. [CrossRef]

60. Xu, C.; Lei, C.; Meng, L.; Wang, C.; Song, Y. Chitosan as a barrier membrane material in periodontal tissue regeneration. J. Biomed. Mater. Res. Part B Appl. Biomater. 2012, 100, 1435-1443. [CrossRef] [PubMed]

61. Lima, P.S.; Trocolli, R.; Wellen, R.M.R.; Rojo, L.; Lopez-Manchado, M.A.; Fook, M.V.L.; Silva, S.M.L. HDPE/chitosan composites modified with PE-g-MA. thermal, morphological and antibacterial analysis. Polymers 2019, 11, 1559. [CrossRef] [PubMed] 
62. Ezati, M.; Safavipour, H.; Houshmand, B.; Faghihi, S. Development of a PCL/gelatin/chitosan/ $\beta-\mathrm{TCP}$ electrospun composite for guided bone regeneration. Prog. Biomater. 2018, 7, 225-237. [CrossRef]

63. Chen, J.L.; Zhao, Y. Effect of Molecular Weight, Acid, and Plasticizer on the Physicochemical and Antibacterial Properties of $\beta$-Chitosan Based Films. J. Food Sci. 2012, 77, 127-136. [CrossRef]

64. Mellegård, H.; Strand, S.P.; Christensen, B.E.; Granum, P.E.; Hardy, S.P. Antibacterial activity of chemically defined chitosans: Influence of molecular weight, degree of acetylation and test organism. Int. J. Food Microbiol. 2011, 148, 48-54. [CrossRef] [PubMed]

65. Kaya, M.; Baran, T.; Erdoğan, S.; Menteş, A.; Aşan Özüsağlam, M.; Çakmak, Y.S. Physicochemical comparison of chitin and chitosan obtained from larvae and adult Colorado potato beetle (Leptinotarsa decemlineata). Mater. Sci. Eng. C 2014, 45, 72-81. [CrossRef] [PubMed]

66. Zhou, T.; Liu, X.; Sui, B.; Liu, C.; Mo, X.; Sun, J. Development of fish collagen/bioactive glass/chitosan composite nanofibers as a GTR/GBR membrane for inducing periodontal tissue regeneration. Biomed. Mater. 2017, 12. [CrossRef] [PubMed]

67. Ma, S.; Adayi, A.; Liu, Z.; Li, M.; Wu, M.; Xiao, L.; Sun, Y.; Cai, Q.; Yang, X.; Zhang, X.; et al. Asymmetric collagen/chitosan membrane containing minocycline-loaded chitosan nanoparticles for guided bone regeneration. Sci. Rep. 2016, 6, 31822. [CrossRef] [PubMed]

68. Saarani, N.N.; Jamuna-Thevi, K.; Shahab, N.; Hermawan, H.; Saidin, S. Antibacterial efficacy of triple-layered poly(Lactic-co-glycolic acid)/nanoapatite/lauric acid guided bone regeneration membrane on periodontal bacteria. Dent. Mater. J. 2017, 36, 260-265. [CrossRef]

69. Martín-del-Campo, M.; Sampedro, J.G.; Flores-Cedillo, M.L.; Rosales-Ibañez, R.; Rojo, L. Bone Regeneration Induced by Strontium Folate Loaded Biohybrid Scaffolds. Molecules 2019, 24, 1660. [CrossRef]

70. Ding, Y.; Li, W.; Correia, A.; Yang, Y.; Zheng, K.; Liu, D.; Schubert, D.W.; Boccaccini, A.R.; Santos, H.A.; Roether, J.A. Electrospun Polyhydroxybutyrate/Poly( $\epsilon$-caprolactone)/Sol-Gel-Derived Silica Hybrid Scaffolds with Drug Releasing Function for Bone Tissue Engineering Applications. ACS Appl. Mater. Interfaces 2018, 10, 14540-14548. [CrossRef]

71. Hamlekhan, A.; Moztarzadeh, F.; Mozafari, M.; Azami, M.; Nezafati, N. Preparation of laminated poly $(\varepsilon-$ caprolactone)-gelatin-hydroxyapatite nanocomposite scaffold bioengineered via compound techniques for bone substitution. Biomatter 2011, 1, 91-101. [CrossRef]

72. Thai, T.H.; Nuntanaranont, T.; Kamolmatyakul, S.; Meesane, J. In vivo evaluation of modified silk fibroin scaffolds with a mimicked microenvironment of fibronectin/decellularized pulp tissue for maxillofacial surgery. Biomed. Mater. 2018, 13. [CrossRef]

73. Timin, A.S.; Muslimov, A.R.; Lepik, K.V.; Saprykina, N.N.; Sergeev, V.S.; Afanasyev, B.V.; Vilesov, A.D.; Sukhorukov, G.B. Triple-responsive inorganic-organic hybrid microcapsules as a biocompatible smart platform for the delivery of small molecules. J. Mater. Chem. B 2016, 4, 7270-7282. [CrossRef]

74. Timin, A.S.; Muslimov, A.R.; Zyuzin, M.V.; Peltek, O.O.; Karpov, T.E.; Sergeev, I.S.; Dotsenko, A.I.; Goncharenko, A.A.; Yolshin, N.D.; Sinelnik, A.; et al. Multifunctional Scaffolds with Improved Antimicrobial Properties and Osteogenicity Based on Piezoelectric Electrospun Fibers Decorated with Bioactive Composite Microcapsules. ACS Appl. Mater. Interfaces 2018, 10, 34849-34868. [CrossRef] [PubMed]

75. Cornelsen, M.; Probst, F.A.; Schwarz, C.; Burian, E.; Tröltzsch, M.; Otto, S.; Saller, M.M.; Schieker, M.; Seitz, H. Mechanical and biological effects of infiltration with biopolymers on 3D printed tricalciumphosphate scaffolds. Dent. Mater. J. 2017, 36, 553-559. [CrossRef] [PubMed]

76. Sarasam, A.R.; Brown, P.; Khajotia, S.S.; Dmytryk, J.J.; Madihally, S.V. Antibacterial activity of chitosan-based matrices on oral pathogens. J. Mater. Sci. Mater. Med. 2008, 19, 1083-1090. [CrossRef] [PubMed]

77. Sarasam, A.; Madihally, S.V. Characterization of chitosan-polycaprolactone blends for tissue engineering applications. Biomaterials 2005, 26, 5500-5508. [CrossRef]

78. Thoma, D.S.; Jung, R.E.; Schneider, D.; Cochran, D.L.; Ender, A.; Jones, A.A.; Görlach, C.; Uebersax, L.; Graf-Hausner, U.; Hämmerle, C.H.F. Soft tissue volume augmentation by the use of collagen-based matrices: A volumetric analysis. J. Clin. Periodontol. 2010, 37, 659-666. [CrossRef]

79. Agis, H.; Collins, A.; Taut, A.D.; Jin, Q.; Kruger, L.; Görlach, C.; Giannobile, W.V. Cell population kinetics of collagen scaffolds in Ex Vivo oral wound repair. PLoS ONE 2014, 9, e112680. [CrossRef]

80. Özmeriç, N.; Özcan, G.; Haytaç, C.M.; Alaaddinoğlu, E.E.; Sargon, M.F.; Şenel, S. Chitosan film enriched with an antioxidant agent, taurine, in fenestration defects. J. Biomed. Mater. Res. 2000, 51, 500-503. [CrossRef] 
81. Park, K.M.; Lee, H.J.; Koo, K.T.; Ben Amara, H.; Leesungbok, R.; Noh, K.; Lee, S.C.; Lee, S.W. Oral Soft Tissue Regeneration Using Nano Controlled System Inducing Sequential Release of Trichloroacetic Acid and Epidermal Growth Factor. Tissue Eng. Regen. Med. 2020, 17, 91-103. [CrossRef]

82. Madi, M.; Kassem, A. Topical simvastatin gel as a novel therapeutic modality for palatal donor site wound healing following free gingival graft procedure. Acta Odontol. Scand. 2018, 76, 212-219. [CrossRef]

83. Park, J.S.; Choi, S.H.; Moon, I.S.; Cho, K.S.; Chai, J.K.; Kim, C.K. Eight-week histological analysis on the effect of chitosan on surgically created one-wall intrabony defects in beagle dogs. J. Clin. Periodontol. 2003, 30, 443-453. [CrossRef]

84. Li, N.; Jiang, L.; Jin, H.; Wu, Y.; Liu, Y.; Huang, W.; Wei, L.; Zhou, Q.; Chen, F.; Gao, Y.; et al. An enzymeresponsive membrane for antibiotic drug release and local periodontal treatment. Colloids Surf. B Biointerfaces 2019, 183, 110454. [CrossRef] [PubMed]

85. Asensio; Vázquez-Lasa; Rojo Achievements in the Topographic Design of Commercial Titanium Dental Implants: Towards Anti-Peri-Implantitis Surfaces. J. Clin. Med. 2019, 8, 1982. [CrossRef] [PubMed]

86. Zhao, L.; Chu, P.K.; Zhang, Y.; Wu, Z. Antibacterial coatings on titanium implants. J. Biomed. Mater. Res. Part B Appl. Biomater. 2009, 91, 470-480. [CrossRef] [PubMed]

87. Han, A.; Tsoi, J.K.H.; Rodrigues, F.P.; Leprince, J.G.; Palin, W.M. Bacterial adhesion mechanisms on dental implant surfaces and the influencing factors. Int. J. Adhes. Adhes. 2016, 69, 58-71. [CrossRef]

88. Palla-Rubio, B.; Araújo-Gomes, N.; Fernández-Gutiérrez, M.; Rojo, L.; Suay, J.; Gurruchaga, M.; Goñi, I. Synthesis and characterization of silica-chitosan hybrid materials as antibacterial coatings for titanium implants. Carbohydr. Polym. 2019, 203, 331-341. [CrossRef]

89. Chua, P.H.; Neoh, K.G.; Shi, Z.; Kang, E.T. Structural stability and bioapplicability assessment of hyaluronic acid-chitosan polyelectrolyte multilayers on titanium substrates. J. Biomed. Mater. Res. Part A 2008, 87, 1061-1074. [CrossRef]

90. Pezzotti, G.; Marin, E.; Adachi, T.; Lerussi, F.; Rondinella, A.; Boschetto, F.; Zhu, W.; Kitajima, T.; Inada, K.; McEntire, B.J.; et al. Incorporating Si 3 N 4 into PEEK to Produce Antibacterial, Osteocondutive, and Radiolucent Spinal Implants. Macromol. Biosci. 2018, 18, 1800033. [CrossRef]

91. Baghdan, E.; Raschpichler, M.; Lutfi, W.; Pinnapireddy, S.R.; Pourasghar, M.; Schäfer, J.; Schneider, M.; Bakowsky, U. Nano spray dried antibacterial coatings for dental implants. Eur. J. Pharm. Biopharm. 2019, 139, 59-67. [CrossRef]

92. Rojo, L.; Deb, S. Polymer Therapeutics in Relation to Dentistry. Front. Oral Biol. 2015, 17, 13-21. [CrossRef]

93. Muzzarelli, R.A.A.; El Mehtedi, M.; Bottegoni, C.; Aquili, A.; Gigante, A. Genipin-crosslinked chitosan gels and scaffolds for tissue engineering and regeneration of cartilage and bone. Mar. Drugs 2015, 13, 7314-7338. [CrossRef]

94. Meng, G.; He, J.; Wu, Y.; Wu, F.; Gu, Z. Antibiotic-loaded chitosan hydrogel with superior dual functions: Antibacterial efficacy and osteoblastic cell responses. ACS Appl. Mater. Interfaces 2014, 6, 10005-10013. [CrossRef]

95. Van Vlierberghe, S.; Dubruel, P.; Schacht, E. Biopolymer-based hydrogels as scaffolds for tissue engineering applications: A review. Biomacromolecules 2011, 12, 1387-1408. [CrossRef] [PubMed]

96. Garchitorena, M. Bioactive Glasses in Restorative Dentistry. J. Clin. Periodontol. 2016, 2, 1-14. [CrossRef]

97. Maji, K.; Dasgupta, S.; Pramanik, K.; Bissoyi, A. Preparation and Evaluation of Gelatin-Chitosan-Nanobioglass 3D Porous Scaffold for Bone Tissue Engineering. Int. J. Biomater. 2016, 2016, 9825659. [CrossRef] [PubMed]

98. Ur Rehman, M.A.; Bastan, F.E.; Nawaz, Q.; Goldmann, W.H.; Maqbool, M.; Virtanen, S.; Boccaccini, A.R. Electrophoretic deposition of lawsone loaded bioactive glass (BG)/chitosan composite on polyetheretherketone (PEEK)/BG layers as antibacterial and bioactive coating. J. Biomed. Mater. Res. Part A 2018, 106, 3111-3122. [CrossRef] [PubMed]

99. Douglas, T.E.L.; Dziadek, M.; Schietse, J.; Boone, M.; Declercq, H.A.; Coenye, T.; Vanhoorne, V.; Vervaet, C.; Balcaen, L.; Buchweitz, M.; et al. Pectin-bioactive glass self-gelling, injectable composites with high antibacterial activity. Carbohydr. Polym. 2019, 205, 427-436. [CrossRef]

100. Li, W.; Ding, Y.; Yu, S.; Yao, Q.; Boccaccini, A.R. Multifunctional Chitosan-45S5 Bioactive Glass-Poly(3hydroxybutyrate-co-3-hydroxyvalerate) Microsphere Composite Membranes for Guided Tissue/Bone Regeneration. ACS Appl. Mater. Interfaces 2015, 7, 20845-20854. [CrossRef] 
101. Zhou, T.; Sui, B.; Mo, X.; Sun, J. Multifunctional and biomimetic fish collagen/bioactive glass nanofibers: Fabrication, antibacterial activity and inducing skin regeneration in vitro and in vivo. Int. J. Nanomed. 2017, 12, 3495-3507. [CrossRef]

102. Quiñones, M.; Miguel, M.; Aleixandre, A. The polyphenols, naturally occurring compounds with beneficial effects on cardiovascular disease. Nutr. Hosp. 2012, 27, 76-89. [CrossRef]

103. Gómez-Florit, M.; Monjo, M.; Ramis, J.M. Identification of Quercitrin as a Potential Therapeutic Agent for Periodontal Applications. J. Periodontol. 2014, 85, 966-974. [CrossRef]

104. Gómez-Florit, M.; Monjo, M.; Ramis, J.M. Quercitrin for periodontal regeneration: Effects on human gingival fibroblasts and mesenchymal stem cells. Sci. Rep. 2015, 5, 16593. [CrossRef] [PubMed]

105. Almaroof, A.; Niazi, S.A.; Rojo, L.; Mannocci, F.; Deb, S. Influence of a polymerizable eugenol derivative on the antibacterial activity and wettability of a resin composite for intracanal post cementation and core build-up restoration. Dent. Mater. 2016, 32, 929-939. [CrossRef] [PubMed]

106. Almaroof, A.; Niazi, S.A.; Rojo, L.; Mannocci, F.; Deb, S. Evaluation of dental adhesive systems incorporating an antibacterial monomer eugenyl methacrylate (EgMA) for endodontic restorations. Dent. Mater. 2017, 33, e239-e254. [CrossRef] [PubMed]

107. Tan, H.L.; Ao, H.Y.; Ma, R.; Lin, W.T.; Tang, T.T. In vivo effect of quaternized chitosan-loaded polymethylmethacrylate bone cement on methicillin-resistant Staphylococcus epidermidis infection of the tibial metaphysis in a rabbit model. Antimicrob. Agents Chemother. 2014, 58, 6016-6023. [CrossRef] [PubMed]

108. Shi, Z.; Neoh, K.G.; Kang, E.T.; Wang, W. Antibacterial and mechanical properties of bone cement impregnated with chitosan nanoparticles. Biomaterials 2006, 27, 2440-2449. [CrossRef]

109. Lewis, G. Properties of nanofiller-loaded poly (methyl methacrylate) bone cement composites for orthopedic applications: A review. J. Biomed. Mater. Res. Part B Appl. Biomater. 2017, 105, 1260-1284. [CrossRef]

110. Wang, M.; Sa, Y.; Li, P.; Guo, Y.; Du, Y.; Deng, H.; Jiang, T.; Wang, Y. A versatile and injectable poly(methyl methacrylate) cement functionalized with quaternized chitosan-glycerophosphate/nanosized hydroxyapatite hydrogels. Mater. Sci. Eng. C 2018, 90, 264-272. [CrossRef]

111. Wang, M.; Feng, X.; Wang, T.; Gao, Y.; Wang, Y.; Sa, Y.; Jiang, T. Synthesis and characterization of an injectable and self-curing poly(methyl methacrylate) cement functionalized with a biomimetic chitosan-poly(vinyl alcohol)/nano-sized hydroxyapatite/silver hydrogel. RSC Adv. 2016, 6, 60609-60619. [CrossRef]

112. Zapata, M.E.V.; Hernandez, J.H.M.; Tovar, C.D.G.; Llano, C.H.V.; Escobar, J.A.D.; Vázquez-Lasa, B.; Román, J.S.; Rojo, L. Novel bioactive and antibacterial acrylic bone cement nanocomposites modified with graphene oxide and chitosan. Int. J. Mol. Sci. 2019, 20, 2938. [CrossRef]

113. Zapata, M.E.V.; Hernandez, J.H.M.; Tovar, C.D.G.; Llano, C.H.V.; Vázquez-Lasa, B.; Román, J.S.; Rojo, L. Osseointegration of antimicrobial acrylic bone cements modified with graphene oxide and chitosan. Appl. Sci. 2020, 10, 6528. [CrossRef]

114. De Mori, A.; Di Gregorio, E.; Kao, A.P.; Tozzi, G.; Barbu, E.; Sanghani-Kerai, A.; Draheim, R.R.; Roldo, M. Antibacterial PMMA Composite Cements with Tunable Thermal and Mechanical Properties. ACS Omega 2019, 4, 19664-19675. [CrossRef] [PubMed]

115. Rojo, L.; Vázquez, B.; Román, J.S.; Deb, S. Eugenol functionalized poly(acrylic acid) derivatives in the formation of glass-ionomer cements. Dent. Mater. 2008, 24, 1709-1716. [CrossRef] [PubMed]

116. Petri, D.F.S.; Donegá, J.; Benassi, A.M.; Bocangel, J.A.J.S. Preliminary study on chitosan modified glass ionomer restoratives. Dent. Mater. 2007, 23, 1004-1010. [CrossRef] [PubMed]

117. Menezes-Silva, R.; de Oliveira, B.M.B.; Fernandes, P.H.M.; Shimohara, L.Y.; Pereira, F.V.; Borges, A.F.S.; Buzalaf, M.A.R.; Pascotto, R.C.; Sidhu, S.K.; de Lima Navarro, M.F. Effects of the reinforced cellulose nanocrystals on glass-ionomer cements. Dent. Mater. 2019, 35, 564-573. [CrossRef]

118. Ibrahim, M.A.; Neo, J.; Esguerra, R.J.; Fawzy, A.S. Characterization of antibacterial and adhesion properties of chitosan-modified glass ionomer cement. J. Biomater. Appl. 2015, 30, 409-419. [CrossRef]

119. Debnath, A.; Kesavappa, S.B.; Singh, G.P.; Eshwar, S.; Jain, V.; Swamy, M.; Shetty, P. Comparative evaluation of antibacterial and adhesive properties of chitosan modified glass ionomer cement and conventional glass ionomer cement: An in vitro study. J. Clin. Diagn. Res. 2017, 11, ZC75-ZC78. [CrossRef]

120. Ibrahim, M.A.; Meera Priyadarshini, B.; Neo, J.; Fawzy, A.S. Characterization of Chitosan/TiO2 Nano-Powder Modified Glass-Ionomer Cement for Restorative Dental Applications. J. Esthet. Restor. Dent. 2017, 29, 146-156. [CrossRef] 
121. Zhou, J.; Xu, Q.; Fan, C.; Ren, H.; Xu, S.; Hu, F.; Wang, L.; Yang, K.; Ji, Q. Characteristics of chitosan-modified glass ionomer cement and their effects on the adhesion and proliferation of human gingival fibroblasts: An in vitro study. J. Mater. Sci. Mater. Med. 2019, 30, 39. [CrossRef]

122. Wu, T.; Hua, X.; He, Z.; Wang, X.; Yu, X.; Ren, W. The bactericidal and biocompatible characteristics of reinforced calcium phosphate cements. Biomed. Mater. 2012, 7, 045003. [CrossRef]

123. Moncif, N.; Gourri, E.L.H.; Elouahli, A.B.A.; Ezzahmouly, M.; Nayme, K.; Timinouni, M.; Hatim, Z. Characterization of bio-composite apatite/chitosan cement and its antibacterial activity. Orient. J. Chem. 2018, 34, 1765-1773. [CrossRef]

Publisher's Note: MDPI stays neutral with regard to jurisdictional claims in published maps and institutional affiliations.

(C) 2020 by the authors. Licensee MDPI, Basel, Switzerland. This article is an open access article distributed under the terms and conditions of the Creative Commons Attribution (CC BY) license (http://creativecommons.org/licenses/by/4.0/). 